\title{
Beyond Narrative Disclosure Tone: The Upper Echelons Theory Perspective
}

\section{Authors:}

Hesham Bassyouny*

University of Portsmouth, UK

Alexandria University, Egypt

*Correspondent author

Address: Richmond Building, Portland St, Portsmouth PO1 3DE, UK.

Email: Hesham.bassyouny@ myport.ac.uk

\section{Tarek Abdelfattah}

University of Portsmouth, UK

Mansoura University, Egypt

Address: Richmond Building, Portland St, Portsmouth PO1 3DE, UK.

Email: tarek.abdelfattah@port.ac.uk

Lei Tao

University of Reading, UK

Address: Whiteknights, Reading, RG6 6UD, UK.

Email: lei.tao@henley.ac.uk 


\begin{abstract}
:
This study investigates the key drives of narrative tone in the UK context where managers have more flexibility to frame narratives with stakeholders. While prior studies examined firm-specific characteristics as determinants of narrative tone, the current study employs the upper echelons theory and focusses on top managers' characteristics. Using computerised textual analysis, our findings suggest that both observed and unobserved CEOs characteristics drive positive tone in the UK context and this relationship is moderated by corporate governance attributes. Specifically, older, female and financial expert CEOs display less positive tone. Considering psychological features, we find that narcissistic CEOs are more likely to display positive tone compared with non-narcissistic CEOs, however, this relationship declines in firms that have a higher independent board. Moreover, we found audit committee and board independence are negatively associated with positive tone. Additionally, we found more females on board increases the negative relationship between female CEOs and positive tone. These results have significant implications for top management, policy makers, regulators and the users of financial reporting.
\end{abstract}

Keywords: Narrative tone, Textual analysis, CEO characteristics, Corporate Governance, Upper echelons theory.

JEL Classification: G34. G40. M48. 


\section{Introduction:}

Narratives play an important role in conveying information from managers to external users (Loughran and Mcdonald, 2016; Merkley, 2014). Prior accounting and financial reporting studies investigated several types of narrative disclosure, such as risk disclosure (e.g., Linsley and Shrives, 2006; Elshandidy, Fraser and Hussainey, 2015; Ibrahim and Hussainey, 2019), Corporate Social Responsibility (CSR) disclosure (e.g., Gray, Kouhy and Lavers, 1995; Dhaliwal, Li, Tsang and Yang, 2011), and Forward-Looking disclosure (e.g., Hussainey, Schleicher and Walker, 2003; Schleicher and Walker, 2010). However, it is important to investigate not only what the information in such a context is, but also how it is being presented to external users (Pennebaker, Mehl and Niederhoffer, 2003; Blankespoor, 2018). This motivates us to focus on Narrative Disclosure Tone (NDT).

Tone refers to how information is linguistically, positive vs. negative, presented to external users in narrative reporting (Henry and Leone, 2016; Loughran and McDonald, 2016). The great majority of NDT studies investigated tone consequences and how it affects market reaction, stock volatility and firm performance (e.g., Tetlock, 2007; Kothari, Li and Short, 2009; Feldman, Govindaraj, Livnat and Segal, 2010; Davis and Tama-Sweet, 2012; Davis, Piger, and Sedor, 2012; Price, Doran, Peterson and Bliss, 2012; Clatworthy and Jones, 2003: Huang, Teoh and Zhang, 2014; Yekini, Wisniewski and Millo, 2016; Boudt, Thewissen and Torsin, 2018; Barakat, ashby, Fenn and Bryce, 2019; Rahman, 2019). However, studies of NDT determinants are limited (Marquez-Illescas, Zebedee and Zhou, 2019; Loughran and McDonald, 2016; Davis, Ge, Matsumoto and Zhang, 2015). Therefore, this study aims to investigate the key factors that drive NDT by responding to the call of Marquez-Illescas et al., (2019) which is asking for more research about NDT determinants.

While prior researchers examined firm-specific characteristics as determinants of NDT (e.g., Li, 2010; Iatridis, 2016), in the current study we move from firm-specific characteristics to top managers' characteristics. This point of view is supported by upper echelons theory, which states that strategic choices and firms' outcomes are predicted by their top managers' characteristics (Hambrick and Mason, 1984). Although Chief Executive Officers (CEOs) are not involved directly in preparing financial reports, they determine the tone of the top, which affects the decisions of different managers (Gounopoulos and Pham, 2018). Therefore, we consider CEO observed personalities (age, gender, and financial expertise), unobserved psychological features (narcissism) and Corporate Governance (CG) mechanisms as determinants of NDT. Given the importance of these arguments, we propose that such characteristics might be reflected in corporate narrative tone. Moreover, it can be moderated by CG mechanisms, which play an important role in monitoring financial reporting process and in declining impression management in narrative reporting (Iatridis, 2016). 
It is worth mentioning that most of the NDT studies used US data, however, more evidence from outside the US is still needed (Yekini et al., 2016; Marquez-Illescas et al., 2019). Therefore, we provide evidence from the UK context that operates under the principles-based approach, which gives managers more flexibility to frame narratives with stakeholders compared with the US where the rules-based approach is applied (Yekini et al., 2016).

Using Loughran and McDonald (2011) wordlist, we employ a computerised textual analysis for UK annual reports narratives, after excluding auditor reports and notes of financial statements, to measure the tone. Our final sample consists of 2,437 firm-year observations from 2010 to 2018. We chose Loughran and McDonald (2011) wordlists because it is created based on a financial document; therefore, it is more applicable to financial reporting and business communication research(Loughran and McDonald, 2016). Following psychological literature we measure narcissism using the firstperson pronounce usage (Alli, Nicolaides and Craig, 2018; Libby, Kristina and Rennekamp, 2012). We focus on annual reports as they provide the largest sample of corporate narrative reporting which can represent corporate narrative style (Wisniewski and Yekini, 2015; Yekini et al., 2016).

Our findings show that both observed and unobserved CEO characteristics and CG mechanisms drive NDT in the UK context as older CEOs, female CEOs and CEOs with financial experience display less positive tone in annual report narratives. Additionally, narcissistic CEOs are more likely to have a positive tone compared with non-narcissistic CEOs. Moreover, we found companies with a high independence level of board of directors and audit committee have less positive tone in their narrative reporting. Considering the moderation influences of $\mathrm{CG}$, we found the positive tone of narcissistic CEOs is lower when firms have a higher board independence percentage. In addition, we found more females on a board increases the negative relationship between female CEOs and positive tone. That is in line with business ethics research suggesting that a higher female percentage on board is associated with appointing a female leader and supporting their decisions as it reduces the gender gap effect between the CEO and the board of directors (Wang and Kelen, 2013).

Our study makes several contributions to financial reporting literature. First, it adds to the de bate on key factors that drive NDT by highlighting CEOs' personalities, psychological feature and financial expertise as new dimensions of NDT determinants. Second, it sheds light on the important role of strong $\mathrm{CG}$ attributes in moderating the positive tone of CEOs. In particular, it shows the role of independent boards in moderating the positive tone of narcissistic CEOs, also, how females on a board affect the tone of female CEOs. Third, to the best of our knowledge, our study is the first in the UK context to provide supporting evidence from upper echelons theory that CEOs' characteristics affect NDT, where the principles-based approach is operated with less restrictive financial reporting style compared with the US context. 
The rest of the article is organised as follows: Section 2 discusses prior literature in NDT and hypotheses development, while the methodology and research design are presented in section 3, and section 4 focusses on data sources and sample selection. The results of our empirical analysis and robustness checks are shown in section 5. Finally, section 6 offers the conclusion of the current study and implications.

\section{Literature review and hypotheses development:}

\subsection{Prior studies of NDT determinants:}

A few studies have investigated the factors that drive the tone of narrative reporting, however, these studies are limited. Li (2010) used the Naïve Bayesian machine learning approach to examine the content of MD\&A section in 10-Q and 10-K filings. He found that firms of a small size, old age, better performance, less volatility and lower accruals are more likely to have a more optimistic tone in their forward-looking statements. Similarly, Schleicher and Walker (2010) examined how managers use tone in their forward-looking statements (FLS) in the outlook section of the UK annual reports. They found that companies with a declining performance are more likely to bias the tone upwards. In addition, they reported that, risky companies and companies that have analyst earnings expectations display a more optimistic tone. Moreover, Schleicher (2012) found that positive FLS are real-good news when they are related more to sales and comparisons with the previous year's results; otherwise, it is just tone management.

Iatridis (2016) aimed to examine accounting strategies and choices as determinants of tone in UK narrative reporting. He found companies with lower earning manipulations, lower cost of capital, high conservatism, and high growth have a more pessimistic tone in their annual reports narratives. Moreover, Davis et al., (2015) reported that managers who have previous experience in charity organisations are more likely to use a more positive tone. In a different way, Lee and Park (2019) found that audit committees with more financial expertise reduce the abnormal optimistic tone in MD\&A section in the US context. In addition, Davis and Tama-Sweet (2012) considered analysts' expectations as determinants of narrative tone. They found firms that beat the analyst's expectation and companies with high growth ratio display less pessimistic language in US press releases.

Recently, using experiments with experienced managers, Asay, Libby and Rennekamp (2018) found CEOs highlight positive information by making it more readable. In addition, they discuss poor performance in a positive way by focussing on future plans. However, managers use less readable, more passive sentences in the case of negative news. Moreover, DeBoskey, Luo and Zhou (2019) found a positive association between CEO power and optimistic tone in US earnings announcement. As they found, longer CEO tenure and having rule duality increase the optimistic tone. However, 
CEO tenure has less effect on narrative tone when the company has efficient corporate governance mechanisms. However, other CEO characteristics might be more related to the tone settings such as narcissism and financial expertise, which we investigate in the current study.

The current study is different from prior studies that have investigated CEO characteristics and NDT (e.g., Marquez-Illescas et al., 2019; DeBoskey et al., 2019) as follows. First, it discusses different characteristics of CEOs, such as age, gender and financial expertise. Second, it investigates not only how CEOs' characteristics might affect NDT, but also the moderation effect of CG mechanisms on this relationship. Third, while the great majority of tone studies examined the US context, the current study provides evidence from the UK, which represents the principle-based approach context where managers have more freedom to frame narratives compared with the US context with more restrictive regulations. Finally, it focusses on annual reports as they provide the largest sample of narrative reporting which can represent corporate narrative style compared with other financial reporting documents such as press releases and conference calls (Yekini et al., 2016).

\subsection{Hypotheses development:}

According to the previous discussion, it is noticeable that prior studies about the determinants of NDT investigated the tone of a specific kind of disclosure, such as the tone of forward-looking disclosure (e.g., Li, 2010; Schleicher and Walker). Alternatively, they considered firm-specific characteristics and firm accounting strategies, such as earning management and accounting conservatism, as determinants of tone (e.g., Iatridis, 2016; Davis and Tama-Sweet, 2012). However, in the current study we move from firm-specific characteristics to top managers' characteristics, considering CEOs' personal and psychological characteristics as determinants of NDT. That can be explained by upper echelons theory, which states that strategic choices and firms' outcomes are predicted by their top managers' characteristics (Hambrick and Mason, 1984).

\subsubsection{CEO characteristics:}

Managers have a key role in choosing a firm's strategy and decision-making as their objective is to increase the wealth of their investors (Amernic and Craig, 2010). Consistently, upper echelons theory argues that a firm's outcomes can be predicted by their top managers' characteristics (Hambrick and Mason, 1984; Chatterjee and Hambrick, 2007). Although the CEOs of companies are not involved directly in preparing financial reports, they determine the tone of the top, which affects the decisions of different managers (Gounopoulos and Pham, 2018). We classify CEO characteristics to observed and unobserved features as follow: 


\subsubsection{CEO observed characteristics:}

\subsection{CEO age:}

Recently, some physiological research suggested that older individuals are more conscientiousness as they are more responsible compared with younger individuals, therefore, they might provide a neutral and fair description for a firm's performance (Ashton and Lee, 2016). Moreover, older CEOs are more likely to have conservatism and cautious strategies in their decision making process (Hambrick and Mason, 1985). In addition, Huang, Rose-Green and Lee (2012) found positive association between CEO age and financial reporting quality. Moreover, previous literature found that CEO age is positively associated with risk aversion and negatively associated with stock volatility (Serfling, 2014). McClelland, III and Oh (2012) reported younger CEOs lead to lower future performance in the US as they argued that older CEOs have more experience to improve firm performance. According to the previous discussion, such a characteristic might be reflected in corporate narrative tone as more conservatism and risk aversion may lead to less optimistic tone. Therefore, the current study expects companies with older CEOs to have less positive tone in their narrative reporting.

H1a: Companies with older CEOs display less positive tone in UK corporate annual report narratives.

\subsection{CEO Gender:}

Recently, the gender of CEOs has been widely investigated in financial reporting literature. According to business ethics literature, genders behave differently in their decision-making, values and interests. Also, they have different responsibilities, understanding and risk preferences (Habib and Hossain, 2013; Zalata, Ntlm, Aboud and Gyapong, 2018). Men are more interested in increasing the economic benefits and have more probability of breaking the rules in order to achieve great success. However, female managers are more ethical in their attitude and decision-making (Butz and Lewis, 1996; Mason and Mudrack, 1996). Gul, Hutchinson, and Lai (2011) argue that having female directors enhances shareholder value and leads to better organisational outcomes.

In addition, Dunn (2010) found females are more likely to overestimate and realise their responsibilities as a CEO compared to men. Whereas there is other evidence that female CEOs are more likely to be risk avoiders, follow conservative strategies and are less likely to be involved in earning management strategies (Zalata et al., 2018A; Davis et al., 2015; Palvia et al. 2015; Peni and Vahamaa 2010). Moreover, Ho, Li, Tam and Zhang (2015) found female CEOs have a strong ethical nature, which leads to a better level of honesty in their financial reporting compared to male CEOs. Consistent with these findings, Faccio, Marchica and Mura (2016) found that companies with female 
CEOs have less earnings volatility and leverage ratios compared with male CEOs. According to the previous discussion, it is noticeable that female CEOs are more risk avoiders, which can be reflected in narrative reporting. Therefore, the current study expects companies with female CEOs to have less positive tone in their narrative reporting.

H1b: Companies with female CEOs display less positive tone in UK corporate annual report narratives.

Moreover, the current study proposes that the effect of a female CEO on positive tone is likely to be moderated by board gender diversity. In particular, we argue that the effect of a female CEO on positive tone is likely to be stronger when there is a higher percentage of females on the board of directors. We based this argument on business ethics research suggesting that a higher percentage of females on board plays an important role in appointing a female leader for the company, as that might reduce the gender gap effect between the CEO and the board of directors (e.g., Wang and Kelen, 2013). In addition, it is important to consider the interdependencies between the top management team as it affects the firm's outcomes (Plöckinger et al., 2016).

H1b1: the relationship between female CEOs and positive tone is moderated by the percentage of females on board.

\subsection{CEO financial expertise:}

Financial expertise is one of the most important attributes to monitor firm performance and a company's mechanisms (Zalata, Tauringana and Tingbani, 2018). Beekes, Pope, and Young (2004) argued that to be able to understand the financial reporting and financial decision consequences, managers should have a financial experience. Moreover, Custódio and Metzger (2014) found that CEOs with a financial experience are more able in their communication with investors because they understand what they need. While the majority of previous studies focussed on higher education and CEOs with a Master of Business Administration (MBA) degree (e.g., Lin, Lin, Song and Li, 2011; Bamber, Jiang and Wang, 2010), Gounopoulos and Pham (2018) argue that CEOs' financial expertise might play a key role in financial reporting quality. They found CEOs with a financial experience are less likely to be involved in earning management strategies compared with non-financial expert CEOs.

Moreover, CEOs with accounting backgrounds are more likely to follow conservative strategies in their financial decisions (Bamber, John, and Yanyan, 2010; Dyreng, Hanlon, and Maydew, 2010). Similarly, Jiang, Zhu, and Huang (2013) found CEOs with financial expertise reduce real earning management and they disclose higher quality earning information. According to the previous 
discussion, CEOs with a financial experience follow more conservative strategies, therefore, the current study expects companies with financial expertise CEOs to have less positive tone in their narrative reporting.

H1c: Companies with financial expertise CEOs display less positive tone in UK corporate annual report narratives.

\subsubsection{CEO unobserved feature (Narcissism):}

In the last decade, there was a growing interest to study the effect of narcissistic CEOs in management, leadership and organisational studies as one of the CEO features (Wales, Patel and Lumpkin, 2013). Olsen, Dworkis and Young (2014) reported that the psychology literature defined narcissism as people who fall in love with themselves and with their own reflections as a kind of self-admiration. According to upper echelons theory, narcissistic CEOs choose different types of strategies compared with other CEOs as they found narcissistic CEOs prefer bold actions, which attract attention, regardless of whether these result in big gains or big losses (Chatterjee and Hambrick, 2007; Buchholz, Jaeschke, Lopatta and Maas, 2018). In other words, the performance of firms which are led by a narcissistic CEO is not better nor worse than other firms because they just focus on the bold action whether it leads to a better performance or not.

Supporting this argument, Olsen et al., (2014) found positive financial performance from narcissistic CEOs. However, Ham, Seybert and Wang, (2018) reported negative association between CEO narcissism and firm performance and financial position. In addition, they reported that firms, which have narcissistic CEOs, are more likely to have lower profitability and cash flows. Recently, Marquez-Illescas et al., (2019) found narcissistic CEOs are more likely to use more optimistic tone in their narrative reporting compared to non-narcissistic CEOs, but this relationship is weaker in firms with older CEOs. However, our study adds to this research by examining if strong CG mechanisms moderate the tone of CEOs.

The great majority of prior studies and the upper echelons theory agreed that narcissistic CEOS aim to take attention and focus on bold actions. Consequently, this study expects that narcissistic CEOs will have more optimistic tone in their narrative reporting and follow more impression management strategies regardless of whether their companies display a good performance or not during the previous year (Ham et al., 2018; Marquez-Illescas et al., 2019; Amernic and Craig, 2010).

H2: Narcissistic CEOs are more likely to use positive tone in their narrative reporting compared with other CEOs in the UK context. 
Moreover, the current study argues that the effect of narcissistic CEOs on positive tone can be moderated by board independence. In other words, we expect that the effect of narcissistic CEOs on positive tone is likely to be lower in the case of a higher independent board of directors. As an independent board represents strong CG mechanisms and increases the governance-monitoring role of executives in order to improve financial reporting quality (Iatridis, 2016; Osma and Guillamo'nSaorín, 2011).

H2a: The positive effect of narcissistic CEOs on positive tone is lower in firms with a higher board independence percentage.

\subsubsection{CG mechanisms:}

Strong and efficient CG improves the quality of financial reporting. In addition, it increases the transparency and decreases the scepticism of investors (Li, 2010; Iatridis, 2016; Melloni, Stacchezzini and Lai, 2016). Therefore, CG mechanisms should be considered as important factors that drive NDT.

\subsubsection{Audit committee independence:}

The Audit Committee (AC) has an important role in monitoring the financial reporting progress (Zalata et al., 2018B). Therefore, it is important to consider the characteristics of AC while investigating financial reporting in general and narrative characteristics in particular such as tone. Mangena and Pike (2005) found a positive association between AC characteristics, such as financial expertise and committee independence, with the level of disclosure in interim reports, as independent AC would be more efficient in monitoring financial reporting process.

In the UK context, Smith Committee Report (2003) states that audit committees should revise companies' control systems and risk management as part of their role in monitoring the financial reporting process. In addition, Melloni et al., (2016) found a negative relationship between AC independence and impression management in business model reports. That means independent AC can control impression management strategies. Therefore, the current research expects more independent $\mathrm{AC}$ will control positive tone in narratives.

H3a: There is a negative significant association between audit committee independence and positive tone in corporate annual report narratives.

\subsubsection{Board independence:}

The independence of the board of directors is an important indicator for a strong CG and it is widely used to examine the efficiency of CG mechanisms (Iatridis, 2016). An independent board increases the efficiency of the board in decision making, monitoring roles and choosing the best choices of the 
company (Melloni et al., 2016). Independent directors are more likely to provide executive directors with independent advice without any conflict of interest (Fama and Jensen, 1983). In addition, there are some empirical studies that supported this argument proving that an independent board decreases impression management (Osma and Guillamo'n-Saorı'n, 2011). Moreover, Liao, Luo and Tang (2015) proved that boards that are more independent have more tendency to increase the transparency in their disclosure. Consequently, this study expects that an independent board of directors will control the positive tone of narratives.

H3b: There is a negative significant association between board independence and positive tone in UK corporate annual report narratives.

\subsubsection{Board gender diversity:}

In the last decade, board diversity was identified as one of the most effective mechanisms to improve CG by providing more experiences, different opinions and alternative perspectives (Zhou, Kara and Molyneux, 2019; Poletti-Hughes and Briano-Turrent, 2019). In particular, gender diversity on board received more attention from regulators and started to be considered as an important indicator of CG efficiency. The financial reporting council in their Guidance on Board Effectiveness argues that gender diversity increases options variety in decision-making and gives more experience variety (FRC, 2011). Moreover, the UK Corporate Governance code highlights the importance of gender diversity as part of efficient CG structure (The code, 2016).

In addition, empirical studies provided evidence about the usefulness of having a high female percentage on the board of directors. Females on board affect firm effectiveness and improve a company's reputation, and it has a significant positive effect on firm performance and corporate governance (Brammer, Millington, and Pavelin, 2009). Similarly, a greater female percentage on the board decreases impression management as female directors disclose neutral information (GarcíaSánchez, Suárez-Fernández and Martínez-Ferrero, 2018; Campbell and Minguez-Vera, 2010). Moreover, Gul et al., (2011) proved that female directors are more ethical in their decisions and financial reporting style. According to the previous discussion, it is obvious that board gender diversity plays an important role in decreasing impression management strategies. Therefore, the current study expects firms with a high percentage of females on board to have less positive tone in their narrative disclosure.

H3c: There is a negative significant association between the percentage of femaleson the board of directors and positive tone in UK corporate annual report narratives. 


\section{Methodology:}

\subsection{Tone measurement:}

Since our main objective of the current study is to identify the key factors that drive NDT in the UK context, we employ a computerised textual analysis using bag-of-words approach with software called CFIE to measure the tone. We chose to use CFIE because it is created especially for the UK PDF structure annual reports (El-Haj, Alves, Rayson, Walker and Young, 2020). CFIE software is similar to Diction software; it converts the PDF files to text, therefore, it will be ready for textual analysis using the chosen wordlist. The bag-of-words approach has been commonly used in textual analysis studies in general, and the tone of narratives studies in particular (e.g., Yekini et al., 2016; Marquez-Illescas et al., 2019; Lee and Park, 2019). This approach aims to measure the word frequency in a document based on a list of words representing the examined phenomenon divided by the total number of words in the document (Henry and Leone, 2016).

According to tone literature, there are four main wordlists that have been widely used to capture the word frequency of positive (negative) tone named as, Harvard GI, Diction, Henry (2008) and Loughran and McDonald (2011) wordlists (Loughran and McDonald, 2016). Following the majority of tone studies (e.g., Davis and Tama-Sweet, 2012; Feldman et al., 2010; Huang et al., 2014; Marquez-Illescas et al., 2019; Lee and Park, 2019), the current study uses Loughran and McDonald (2011) wordlist to measure positive tone, for two reasons. First, it is created based on a financial document, named 10-K filings, and therefore, it is more applicable to financial reporting and business communication research than other general dictionaries such as Harvard or Diction (Loughran and McDonald, 2016). Second, it is more comprehensive as it contains 354 positive and 2,329 negative words compared with Henry (2008) wordlist, which contains 104 positive words and 85 negative words. Although Loughran and McDonald (2011) wordlist is created based on the US context, 10-K filings, it is still applicable to be used in the UK context as it does not contain words related to culture or regulations (Yekini et al., 2016). Therefore, positive tone is measured as positive words divided by the total number of words in the annual report to control for document length (Feldman et al., 2010; Davis and Tama-Sweet 2012; Davis et al. 2015; Loughran and McDonald, 2011; ArslanAyaydin, Boudt and Thewissen, 2016; Yekini et al., 2016).

The current study focusses on positive tone in investigating the key factors that drive NDT as the majority of studies in the UK context argued that firms disclose more positive information than negatives (e.g., Clatworthy and Jones, 2003; Smith and Taffler, 2010; Schleicher and Walker, 2010). Moreover, empirical research suggested that positive words are more accurate in measuring NDT as managers will not aim to use negative words voluntarily (Schleicher and Walker, 2010; Yekini et al., 
2016). However, we use net tone (positive-negative) as a robustness test for our results to control for negativity.

\subsection{CEO narcissism measurement:}

Measuring personal characteristics is very challenging, especially psychological traits such as narcissism (Ham et al., 2018). Narcissism in social science, leadership and psychology studies are commonly measured by the Narcissistic Personality Inventory (NPI-40) developed by Raskin and Terry (1988). The NPI contains 40 pairs of statements of which the CEO must choose one for every pair in order to measure the level of narcissism. However, previous research has argued that it is the CEOs themselves who do this measurement so they may be biased in their choices; therefore, they decided to conduct different measures to capture narcissism. For instance, Ham et al., (2018) used CEO signature size as a proxy of narcissism. Moreover, a composite measure based on the CEO's photo in the annual report, CEO's relative cash pay and CEO's relative non-cash pay were created as a measure of CEO narcissism (Chatterjee and Hambrick, 2007; Olsen et al., 2014).

However, we argue that the CEO compensation, cash pay and non-cash pay, represents the effort and expertise of a CEO, not his/her psychological characteristics. Alternatively, it might be better to use other measurements of narcissism, which reflect CEOs' personalities, such as the use of firstperson pronouns in financial reporting which had been used in psychology literature to measure narcissism (Li, 2011; Alli et al., 2018). Moreover, sociolinguistics research supported this argument as first-person pronouns allow the provider of the message to link themselves to the good news, but the absence of first-person pronouns distances the provider from the bad news (Libby et al., 2012). Therefore, the current study uses the percentage of first-person pronouns in the CEO letter to shareholders as a proxy of narcissism. However, in our robustness checks we will follow Chatterjee and Hambrick, (2007) in the use of the photo of the CEO in annual reports as a second proxy to capture narcissism, giving a score from 1 to 5 as defined in (table 1). Finally, other variables such as CEO characteristics, CG mechanisms and firm controls are defined in (table 1).

(Table 1 near here)

\subsection{Empirical models:}

We investigate the key factors that drive positive tone in UK annual report narratives using the following regression model: 
Pos_Tone $_{i t}=\propto+\beta_{1} C E O_{-} a g e_{i t}+\beta_{2} C E O_{-}$gender $_{i t}+\beta_{3}$ CEO_FinExp $i t+\beta_{4} A C_{-} I N D_{i t}+$

$\beta_{5} B_{-} I N D_{i t}+\beta_{6} B_{-}$gender diversity $i t+\beta_{7} C E O_{-} D U L_{i t}+\beta_{8} C E O_{-}$tenure ${ }_{i t}+$

$\beta_{9}$ CEO_Founder ${ }_{i t}+\beta_{10}$ CEO_COMP $i t+\beta_{11} F R C_{i t}+\beta_{12}$ B_size $_{i t}+\beta_{13}$ FOG $_{i t}+$

Firm_controls it $_{-}+$Year_FE $+I N D_{-} F E_{i}+\varepsilon_{i t}$

Pos_Tone is measured as positive words divided by the total number of words in the annual report to control for document length (e.g., Davis and Tama-Sweet 2012; Davis et al. 2015; Arslan-Ayaydin et al., 2016; Loughran and McDonald, 2011; Yekini et al., 2016). Other variables in the model that capture CEO personalities and CG mechanisms are explained in (table 1). We control for firm characteristics as follows because they have been considered as important indicators for firm outcomes and strategies (Iatridis, 2016; Li, 2010).

Previous research recommended controlling for Firm_Size as large companies follow more conservative strategies to avoid any future risks, and they will be more cautious about disclosing balanced narrative reports ( $\mathrm{Li}, 2010)$. In addition, we consider financialleverage as a control of credit crunch (Yekini et al., 2016). We also control for other firm-specific characteristics that might affect positive tone such as Sales_growth,Profitability, Dividend and Book-to-Market ratio as a proxy of growth, current profit, investment activities and firm value respectively (Li, 2010; Davis et al., 2015). $F R C$ is a dummy variable equal 1 for years after the FRC narrative reporting guidance in 2014 in order to control for the regulatory guidance. In addition, we control for readability, using FOG index as another important characteristic of narratives because previous research has shown that it is correlated with narrative tone (Tan, Wang and Zhou, 2014). Finally, we control for year and industry fixed effect that might affect the positive tone of annual report narratives (Davis et al., 2015).

In order to investigate the effect of CEO narcissism on positive tone in UK annual report narratives, we use the following regression model:

Pos_Tone $_{i t}=\propto+\beta_{1} C E O_{-} N A R_{i t}+\beta_{2} C E O_{-} a g e_{i t}+\beta_{3} C E O_{-}$gender $_{i t}+\beta_{4}$ CEO_FinExp $i t+$ $\beta_{5} A C_{-} I N D_{i t}+\beta_{6} B_{-} I N D_{i t}+\beta_{7} B_{-}$gender diversity $i t+\beta_{8} C E O_{-} D U L_{i t}+\beta_{9} C E O_{-}$tenure ${ }_{i t}+$ $\beta_{10}$ CEO_Founder $i t+\beta_{11}$ CEO_COMP $i t+\beta_{12} F R C_{i t}+\beta_{13} B_{-}$size $_{i t}+\beta_{14}$ FOG $_{i t}+$ Firm_controls it $_{-}+$Year_FE $+I N D_{-} F E_{i}+\varepsilon_{i t}$

CEO_NAR is measured based on the percentage of first-person pronouns in the CEO letter to shareholders, as mentioned above (e.g., Li, 2011; Libby et al., 2012). Following prior studies that 
investigated CEO narcissism (e.g., Olsen et al., 2014; Marquez-Illescas et al., 2019), we control for other CEO personalities, CG and firm features, while Pos_Tone, other controls for CEO personalities, CG and firm-specific characteristics were measured as explained above in model (1). Moreover, we control for CEO_COMP as compensation is one factor that might affect CEO psychological features (Olsen et al., 2014).

Previous research has argued that even managers' characteristics are important to investigate; however, the interactions within the top management team have implications for companies' outcomes (e.g., Zhang, Ou, Tsui and Wang, 2017). Therefore, the following models (3) and (4) aim to investigate the interaction effects of top management team characteristics on positive tone in UK annual report narratives.

In model (3), we examine the moderation effect of board independence, as a proxy for strong CG, on the relationship between CEO narcissism and positive tone. As explained above in the hypotheses development, strong CG mechanisms increase the governance-monitoring role of executives in order to improve financial reporting quality (Osma and Guillamo'n-Saorı'n, 2011).

$$
\begin{aligned}
& \text { Pos_Tone }_{i t}=\propto+\beta_{1} C E O_{-} N A R_{i t}+\beta_{2} B_{-} I N D_{i t}+\beta_{3} C E O_{-} N A R * B_{-} I N D_{i t}+\beta_{4} C E O_{-} a g e_{i t}+
\end{aligned}
$$

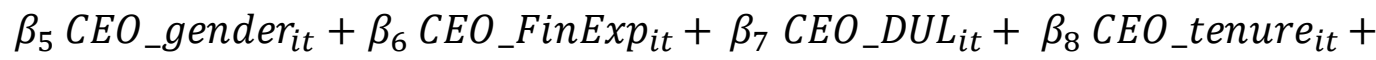

$$
\begin{aligned}
& \beta_{9} C E O_{-} \text {Founder }_{i t}+\beta_{10} \text { CEO_COMP } i t+\beta_{11} F R C_{i t}+\beta_{12} A C_{-} I N D_{i t}+\beta_{13} B_{-} \text {size }_{i t}+ \\
& \beta_{14} B_{-} \text {gender diversity } \text { it }_{15}+\beta_{15} F O G_{i t}+\text { Firm_controls }_{i t}+Y e a r_{-} F E_{t}+I N D_{-} F E_{i}+\varepsilon_{i t}
\end{aligned}
$$

Where $C E O \_N A R^{*} B \_I N D$ represent the interaction between narcissistic CEO and the percentage of independent directors on board Pos_Tone, other controls for CEO personalities, CG and firmspecific characteristics were measured as explained above in model (1).

In model (4), we examine the moderation effect of board gender diversity on the relationship between CEO gender and positive tone. As explained above in the hypotheses development, a higher female percentage on board plays an important role in appointing a female leader for the company as that might reduce the gender gap effect (Wang and Kelen, 2013).

\footnotetext{
Pos_Tone $_{i t}=\propto+\beta_{1}$ CEO_gender ${ }_{i t}+\beta_{2} B_{-}$gender diversity it $+\beta_{3}$ CEO_gender $*$ $B_{-}$gender diversity ${ }_{i t}+\beta_{4} C E O_{-} a g e_{i t}+\beta_{5} C E O \_F i n E x p p_{i t}+\beta_{6} C E O \_D U L_{i t}+$
} 
$\beta_{7}$ CEO_tenure $i t+\beta_{8}$ CEO_Founder $i t+\beta_{9}$ CEO_COMP $i t+\beta_{10} F R C_{i t}+\beta_{11} A C_{-} I N D_{i t}+$ $\beta_{12} B_{-}$size $_{i t}+\beta_{13} B_{-} I N D_{i t}+\beta_{14} F O G_{i t}+F_{i r m}$ controls $i t+Y e a r_{-} F E_{t}+I N D_{-} F E_{i}+\varepsilon_{i t}$

CEO_gender is measured as a dummy variable, as mentioned in table (1) while CEO_gender*B_ gender diversity represent the interaction between $\mathrm{CEO}$ gender and the percentage of female directors on board. Pos_Tone, other controls for CEO personalities, CG and firm-specific characteristics were measured as explained above in model (1).

\section{Data:}

The included companies in our sample are based on FTSE All-Share stock market Index. From all the list, we excluded 283 companies that operate in the financial services sector as they have different regulations, accounting practices and a different structure of financial statements compared with nonfinancial companies (Schleicher and Walker, 2010). Moreover, we excluded 35 companies with missing data and PDF annual reports that were not transferable to text. Therefore, our final sample includes 224 listed companies in the London Stock Exchange from 2010 to 2018. We chose 2010 as a starting point for our sample to avoid the effect of the financial crisis in 2008. Moreover, by selecting this period we will be able to cover annual report narratives before and after the 2014 narrative reporting guidance issued by FRC. For these companies, we collected their available annual reports from Bloomberg and companies' websites manually. This process ended by having 2,437 firm year observations.

It is worth mentioning that the current study focusses on the UK corporate annual report narratives as a unit of textual analysis after excluding the notes of financial statements and the external auditor report since the notes of financial statements are more descriptive and there are no opportunities for tone management in this section (Yekini et al., 2016). Moreover, we exclude the external auditor report because it does not represent corporate narrative reporting as it is written by an independent auditor from outside the company.

Finally, in order to investigate the key factors that drive NDT in the UK context, we collected the data about CEO personal characteristics, CG, firm financial characteristics and other control variable $s$ from Bloomberg. However, in the case of having missing data about CEO personal characteristics in Bloomberg, we collected it manually from annual reports as mentioned above in table (1). 


\section{Empirical results:}

\subsection{Descriptive statistics and correlations:}

Table (2) provides descriptive statistics of our variables in the current study. The mean value of Pos_Tone is 0.018 , suggesting that UK annual report narratives have a positive sentiment. This value is in line with prior literature which measures positive tone scaled by the total number of words to control for document length (e.g., Loughran and McDonald, 2011; Davis and Tama-Sweet, 2012; Davis etal., 2015; Yekini et al., 2016). The average age of CEOs in our study is 53 years old; however, just $4.6 \%$ of the CEOs in our sample are females. These results are close to previous studies that investigated CEO characteristics (e.g., Ho et al., 2015). 20\% of the CEOs in our sample have financial experience and $2.7 \%$ of the CEOs tended to be narcissistic. Moreover, we report that $60.8 \%$ of members on board are independent; however, there is just an average of $15 \%$ as females on board in our sample. The average of dividends per share (DPS) in our sample is 0.22 , and the profitability based on ROE shows an average of 24.9. Moreover, the mean value of BTM ratio is 0.49 , while the value of sales_growth in our sample is $8.24 \%$. These previous results are consistent with prior studies in NDT (e.g., Li, 2010, Davis et al., 2015; Yekini et al., 2016; Marquez-Illescas et al., 2019).

(Table 2 near here)

Table (3) presents the Person correlation between our variables in the current study. This correlation test provides an initial association between our variables and the key variable (Pos_Tone). Moreover, it sheds light on any potential multicollinearity. We found that CEO personal and psychological characteristics are significantly associated with positive tone in UK annual report narratives, which supports upper echelons theory that firms' outcomes are predicted by their top managers' characteristics (Hambrick and Mason, 1984). In addition, we found a significant positive association between CEO_Compensation,firm_Size, ROE and sales_growth with CEO_narcissism. These results suggest that larger firms, firms with high performance and growth ratio, are more likely to appoint narcissistic CEOs with high compensations, which is in line with previous studies (e.g., Chatterjee and Hambrick 2007; Marquez-Illescas et al, 2019). Finally, the correlation between explanatory variables in the current study is relatively low, indicating that there are not any multicollinearity problems in our empirical models.

(Table 3 near here) 


\subsection{Multivariable results and Discussion:}

\subsubsection{Key driving factors of positive tone:}

Table (4) presents the main empirical results of our OLS regression analysis. Column (1) shows the key factors that drive positive tone in the UK annual report narratives (model 1). We found that positive tone in annual report narratives is driven by different factors, named as CEO personalities, CG mechanisms and firm characteristics as these factors explain $19.32 \%$ of the changes in positive tone. We found CEO age is negatively and significantly associated with positive tone, with a coefficient of -0.0032 and t value of -1.91 , supporting H1a that older CEOs display less positive tone. This is consistent with psychological research arguing that older individuals have more conscientiousness; therefore, they might provide a neutral and fair description for a firm's performance (Ashton and Lee, 2016). Female CEOs are negatively and significantly associated with positive tone, with a coefficient of -0.0081 and $t$ value of -1.97 , supporting $\mathrm{H} 1 \mathrm{~b}$ that female CEOs display less positive tone due to having a more ethical attitude in decision-making (Zalata et al., 2018A). Financial expert CEOs are negatively and significantly associated with positive tone, with a coefficient of -0.0025 and $t$ value of -1.39 , supporting $\mathrm{H} 1 \mathrm{c}$ that CEOs with financial experience display less positive tone, which is in line with prior literature showing that financial expert CEOs follow more conservative strategies (Gounopoulos and Pham, 2018). These previous results support upper echelons theory, which assumes that firms' outcomes are predicted by their top managers' characteristics.

Considering CG mechanisms as important factors that might drive positive tone in UK annual reports narratives, we found AC independence is negatively and significantly associated with positive tone, with a coefficient of -0.0028 and $t$ value of -3.15 , and thus supporting $\mathrm{H} 3 \mathrm{a}$ that independent $\mathrm{AC}$ is negatively associated with positive tone. An independent board is negatively and significantly associated with positive tone, with a coefficient of -9.3206 and t value of -1.48 , therefore supporting $\mathrm{H} 3 \mathrm{~b}$, that an independent board is negatively associated with positive tone. In contrast with our expectation, we found a higher percentage of females on board is positively and significantly associated with positive tone, with a coefficient of 0.0025 and $t$ value of 3.31 . Therefore, we reject $\mathrm{H} 3 \mathrm{c}$, assuming that more females on board is negatively associated with positive tone. This can be explained as there is a small percentage of females on board in the UK context compared with prior studies that have been conducted in the US context. As it has been shown in the descriptive statistics, the mean of females on board is $15.58 \%$. Therefore, maybe this percentage does not show the real effect of board gender diversity on board in the UK context. However, in general these results are consistent with prior studies showing that strong CG mechanisms play an important role in monitoring the financial reporting process (Iatridis, 2016; Zalata et al., 2018B). 
Moreover, we control for other CEO characteristics and firm-specific characteristics as important factors that might drive positive tone. We found CEO_Duality and CEO_founder are negatively and significantly associated with positive tone, while CEO_tenure is negatively associated with positive tone but it is not significant. Considering the readability of narratives as another important characteristic of narrative reporting, we found less readable (more complex) narratives are negatively and significantly associated with positive tone. That means when managers provide positive information they formulate it in a way that is easy to read. Firm size is negatively and significantly associated with positive tone, which is consistent with previous literature (e.g., Li, 2010: Marquez-Illescas et al., 2019). Dividend per share, sales growth and profitability are positively and significantly associated with positive tone. These results indicate that higher performance and growth companies use more positive tone in their annual report narratives compared with other companies, in line with previous literature (e.g., Davis et al., 2015; Clatworthy and Jones, 2003). In addition, we found UK companies display more positive tone after the FRC narrative reporting guidance in 2014, compared with the years before.

To investigate if multicollinearity problem affects the results in model (1), we calculate variance inflation factor (VIF). A commonly used value in previous literature that indicates strong or weak multicollinearity is VIF of 10; a VIF above 10 indicates strong multicollinearity (Chatterjee and Price, 1991). The VIF score for this model is 1.64 , and therefore, we conclude that multicollinearity problem does not exist in this model.

\subsubsection{The effect of CEO narcissism on positive tone:}

Column 2 of table (4) presents CEO narcissism as a determinant of positive tone (model 2). We found that CEO narcissism is positively and significantly associated with positive tone, with a coefficient of 0.0041 and $t$ value of 4.23 , which supports $\mathrm{H} 3$ that narcissistic CEOs are more likely to use positive tone compared with non-narcissistic CEOs. This result is consistent with upper echelons theory, which assumes that narcissistic CEOs prefer bold actions, which attract attention, compared with nonnarcissistic CEOs, whether it results in big gains or big losses (Chatterjee and Hambrick, 2007). It is noticeable that R2 increases by $1.13 \%$ from model (1) to model (2), which indicates the explanatory power of CEO narcissism on positive tone.

It is worth mentioning that we control for other CEO personalities, CG mechanisms and firm characteristics, using the same variables as explained above in model (1) results, in our examining of the effect of CEO narcissism on positive tone. The VIF score is 1.61 , and therefore, we conclude that multicollinearity problem does not exist in this model. 


\subsubsection{The moderation effects of $C G$ :}

Table (5) presents the moderation effect of CG on the relationship between CEO personalities and positive tone in the UK annual report narratives. Column (1) of table (5) shows the results for the moderation effect of board independence on the relationship between CEO narcissism and positive tone (model 3). While CEO narcissism remains positively and significantly associated with positive tone, with a coefficient of 0.013 and $\mathrm{t}$ value of 2.33 , we found the interaction between CEO narcissis $\mathrm{m}$ and board independence is negatively and significantly associated with positive tone, with a coefficient of -0.0015 and $t$ value of -1.87 . These results indicate that a higher independence level of the board reduces the positive association between CEO narcissism and positive tone. In other words, strong CG mechanism can control the positive tone of narcissistic CEOs. Therefore, these results support H2a that the positive effect of narcissistic CEOs on positive tone is lower when firms have a higher board independence percentage. The VIF score is 2.46 , and therefore, we conclude that multicollinearity problem does not exist in this model.

Column (2) of table (5) shows the results regarding the moderation effect of board gender diversity on the relationship between CEO gender and positive tone (model 4). Female CEO remains negatively and significantly associated with positive tone with a coefficient of -0.0018 and t value of -2.20 . We found the interaction between female CEOs and the percentage of females on board to be positively and significantly associated with positive tone, with a coefficient of 0.0065 and t value of 2.24 . These results indicate that more females on board increases the negative association between female CEOs and positive tone. Therefore, these results support H1b1 that the negative effect of female CEOs on positive tone is higher in firms with a higher percentage of females on board. Moreover, these results are consistent with business ethics research suggesting that a higher percentage of females on board is associated with appointing a female leader in supporting their decisions as it reduces the gender gap effect between the CEO and the board of directors (Wang and Kelen, 2013). The VIF score is 1.96, and therefore, we conclude that multicollinearity problem does not exist in this model.

\section{(Table 5 near here)}

\subsection{Robustness test:}

\subsubsection{Alternative measure for CEO narcissism:}

In order to check the robustness of our results, we use a different measure for CEO narcissism in models (2) and (3). We used first-person pronoun usage as a proxy for narcissism in our original analysis and followed Chatterjee and Hambrick, (2007) in using the photo of the CEO in annual reports as an alternative proxy to capture narcissism and giving a score from 1 to 5 as defined in (table 
1). Table (6) confirms our main results mentioned above as we found narcissistic CEOs are more likely to use positive tone in narrative reporting compared with non-narcissistic CEOs. However, this relationship is lower when the company has a higher independency level of board of directors. This confirms our hypotheses $\mathrm{H} 2$ and $\mathrm{H} 2 \mathrm{a}$ that narcissistic CEOs have the desire to focus on positive tone in narrative reporting, however, strong CG mechanisms play an important role in monitoring CEO attributes towards positive tone.

(Table 6 near here)

\subsubsection{Controlling for negative tone:}

While we were focussing on positive tone in our main analysis as a proxy of NDT, we aimed to check the robustness of our results by using Net_Tone as a proxy of NDT, measured as (positive words-negative words)/total number of words. In other words, we aim to control for the negative tone in annual report narratives. Table (7) confirms our original results that NDT in annual reports is driven by different factors, named as CEO characteristics, CG mechanisms and firm characteristics. However, we found that the variables coefficient, $t$-value and $R 2$ are lower compared with our main analysis when positive tone was used as a proxy of NDT. These results are not surprising as they are in line with previous studies in the UK context reporting that NDT is more accurate if it is measured by positives rather than negatives as managers tend to bias the number of negative words (Schleicher and Walker, 2010; Yekini et al., 2016). Moreover, they reported that positive words are more in use and have more explanatory power than negatives in the UK context, especially when the principles based approach is operated with less restriction in monitoring financial reporting.

(Table 7 and 8 near here)

In addition, table (7) as a robustness check shows that CEO narcissism is positively associated with Net_Tone; however, it is not significant. In other words, after controlling for negative tone, the significant relationship between narcissistic CEOs and NDT started to dissolve. This is not surprising as upper echelons theory suggests that narcissistic CEOs prefer bold actions, which attract attention by focussing on positives whether it results in big gains or big losses (Chatterjee and Hambrick, 2007; Ham et al., 2018). Therefore, they focus only on positive tone, not negatives, to get more attention. Finally, as a robustness check for our results regarding the moderation effect of CG, table (8) confirms our main results that the moderation effect of CG mechanisms for the relationship between CEO characteristics and NDT is still statistically significant, even after controlling for negative words by using Net_Tone as a proxy of NDT. This means that strong CG mechanisms play an important role in having a balanced (not biased) narrative reporting style. 


\section{Conclusion:}

This study aims to investigate the key factors that drive NDT in UK annual reports. While prior studies examined firm-specific characteristics as determinants of NDT (e.g., Li, 2010; Iatridis, 2016), the current study moves from firm-specific characteristics to top managers' characteristics. We used Loughran and McDonald (2011) wordlist to employ a computerised content analysis for a sample of UK annual report narratives, 2,437 firm observations, in order to capture tone. Our results show that NDT is driven by the characteristics of CEOs and CG attributes as older CEOs, female CEOs and CEOs with financial experience display less positive tone in annual reports narratives. Moreover, we found companies with a high independence level of board of directors and audit committee have less positive tone. Additionally, narcissistic CEOs are more likely to use positive tone compared with nonnarcissistic CEOs, but the positive tone of narcissistic CEOs declines when firms have a higher board independence percentage. Moreover, we report that a higher percentage of females on board supports the attitude of female CEOs towards positive tone. Our results are robust due to the use of another proxy of CEO narcissism and controlling for negative tone.

We contribute to the debate on key factors that drive NDT by highlighting CEOs' personalities, psychological features, financial experience and CG mechanisms as new dimensions of NDT determinants. Moreover, our studies show the role of strong CG in moderating the positive tone of CEOs. In addition, we contribute to NDT literature by providing evidence from the UK context where the principles-based approach is operated with less restriction in monitoring financial reporting compared with the US context. The current study has theoretical and practical implications. Theoretically, it provides supporting evidence for upper echelons theory, which states that strategic choices and firms' outcomes are predicted by their top managers' characteristics (Hambrick and Mason, 1984). Practically, it informs analysts and investors about the characteristics of CEOs who are using more positive tone in their communication with external users through annual reports. Moreover, it shows policy makers the importance of having strong CG in monitoring financial reporting process. This study is not free from limitations. Firstly, because of data restrictions, we used secondary data to capture CEO narcissism. However, future research might use more direct measures such as NPI, as explained above. Secondly, while we focus on annual reports as one unit of textual analysis, future research might split it into different sections, to report about tone consistency in annual reports. Finally, this study focusses on the UK context; however, future research might compare the determinants of NDT between different countries that follow different CG regulatory settings.

\section{Declaration of interest: none.}




\section{References:}

Alli, R., Nicolaides, R., \& Craig, R. (2018). Detecting advance fee fraud emails using self-referential pronouns: A preliminary analysis. Accounting Forum, 42 (1), 78-85. https://doi.org/10.1016/j.accfor.2018.01.003

Amernic, J. H., \& Craig, R. J. (2010). Accounting as a facilitator of extreme narcissism. Journal of business ethics, 96(1), 79-93. https:// DOI 10.1007/s10551-010-0450-0

Arslan-Ayaydin, Ö., Boudt, K., \& Thewissen, J.(2016). Managers set the tone: Equity incentives and the tone of earnings press releases. Journal of Banking \& Finance, 72, S132-S147. https://doi.org/10.1016/j.jbankfin.2015.10.007

Asay, H. S., Libby, R., \& Rennekamp, K. (2018). Firm performance, reporting goals, and language choices in narrative disclosures. Journal of Accounting and Economics, 65(2-3), 380-398. https://doi.org/10.1016/j.jacceco.2018.02.002

Ashton, M. C., \& Lee, K. (2016). Age trends in HEXACO-PI-R self-reports. Journal of Research in Personality, 64, 102-111. http://dx.doi.org/10.1016/j.jrp.2016.08.008

Bamber, L. S., Jiang, J., \& Wang, I. Y. (2010). What's my style? The influence of top managers on voluntary corporate financial disclosure. The accounting review, 85(4), 1131-1162. https:// DOI: 10.2308/accr.2010.85.4.1131

Bamber, L. S., Jiang, J., Petroni, K. R., \& Wang, I. Y. (2010). Comprehensive income: Who's afraid of performance reporting?. The Accounting Review, 85(1), 97-126. https:// DOI: 10.2308/accr.2010.85.1.97

Barakat, A., Ashby, S., Fenn, P., \& Bryce, C. (2019). Operational risk and reputation in financial institutions: Does media tone make a difference?. Journal of Banking \& Finance, 98, 1-24. https://doi.org/10.1016/j.jbankfin.2018.10.007

Bartov, E., Faurel, L., \& Mohanram, P. S. (2017). Can twitter help predict firm-level earnings and stock returns?. The Accounting Review, 93(3), 25-57. https://doi.org/10.2308/accr-51865

Beekes, W., Pope, P., \& Young, S. (2004). The link between earnings timeliness, earnings conservatism and board composition: evidence from the UK. Corporate Governance: An International Review, 12(1), 47-59.

Blankespoor, E. (2018). Firm communication and investor response: A framework and discussion integrating social media. Accounting, Organizations and Society, 68, 80-87. https://doi.org/10.1016/j.aos.2018.03.009 
Boudt, K., Thewissen, J., \& Torsin, W. (2018). When does the tone of earnings press releases matter?. International Review of Financial Analysis, 57, 231-245. https://doi.org/10.1016/j.irfa.2018.02.002

Brammer, S., Millington, A., \& Pavelin, S. (2009). Corporate reputation and women on the board. British Journal of Management, 20(1), 17-29. https:// DOI: 10.1111/j.1467-8551.2008.00600.x

Buchholz, F., Jaeschke, R., Lopatta, K., \& Maas, K. (2018). The use of optimistic tone by narcissistic CEOs. Accounting, Auditing \& Accountability Journal, $31 \quad$ (2), 531-562. https://doi.org/10.1108/AAAJ-11-2015-2292

Butz, C. E., \& Lewis, P. V. (1996). Correlation of gender-related values of independence and relationship and leadership orientation. Journal of Business Ethics, 15(11), 1141-1149.

Campbell, K., \& Vera, A. M. (2010). Female board appointments and firm valuation: Short and long term effects. Journalof Management \& Governance, 14(1), 37-59. https:// DOI 10.1007/s10997-0099092-y

Chatterjee, A., \& Hambrick, D. C. (2007). It's all about me: Narcissistic chief executive officers and their effects on company strategy and performance. Administrative science quarterly,52(3), 351-386.

Chatterjee, S., \& Price, B. (1991). Regression diagnostics. New York: John Wiley.

Clatworthy, M., \& Jones, M. J. (2003). Financial reporting of good news and bad news: evidence from accounting narratives. Accounting and business research, 33(3), 171-185. https://doi.org/10.1080/00014788.2003.9729645

Custódio, C., \& Metzger, D. (2014). Financial expert CEOs: CEO' s work experience and firm' s financial policies. Journal of Financial Economics, 114(1), 125-154. http://dx.doi.org/10.1016/j.jfineco.2014.06.002

Davis, A. K., \& Tama-Sweet, I. (2012). Managers' use of language across alternative disclosure outlets: Earnings press releases versus MD\&A. Contemporary Accounting Research,29(3), 804-837. https://doi.org/10.1111/j.1911-3846.2011.01125.x

Davis, A. K., Ge, W., Matsumoto, D., \& Zhang, J. L. (2015). The effect of manager-specific optimism on the tone of earnings conference calls. Review of Accounting Studies, 20(2), 639-673. https://doi.org/10.1007/s11142-014-9309-4

Davis, A. K., Piger, J. M., \& Sedor, L. M. (2012). Beyond the numbers: Measuring the information content of earnings press release language. Contemporary Accounting Research, 29(3), 845-868. https://doi.org/10.1111/j.1911-3846.2011.01130.x 
DeBoskey, D. G., Luo, Y., \& Zhou, L. (2019). CEO power, board oversight, and earnings announcement tone. Review of Quantitative Finance and Accounting, 52(2), 657-680. https://doi.org/10.1007/s11156-018-0721-x

Dhaliwal, D. S., Li, O. Z., Tsang, A., \& Yang, Y. G. (2011). Voluntary nonfinancial disclosure and the cost of equity capital: The initiation of corporate social responsibility reporting. The accounting review, 86(1), 59-100. https://doi.org/ 10.2308/accr.00000005

Dunn, P. (2012). Breaking the boardroom gender barrier: the human capital of female corporate directors. Journal of Management \& Governance, 16(4), 557-570. https:// DOI 10.1007/s10997-0109161-2

Dyreng, S. D., Hanlon, M., \& Maydew, E. L. (2010). The effects of executives on corporate tax avoidance. The Accounting Review, 85(4), 1163-1189. https://DOI: 10.2308/accr.2010.85.4.1163

El-Haj, M., Alves, P., Rayson, P., Walker, M., \& Young, S. (2019). Retrieving, classifying and analysing narrative commentary in unstructured (glossy) annual reports published as PDF files. Accounting and Business Research, 1-29. https://doi.org/10.1080/00014788.2019.1609346

Elshandidy, T., Fraser, I., \& Hussainey, K. (2015). What drives mandatory and voluntary risk reporting variations across Germany, UK and US?. The British Accounting Review, 47(4), 376-394. https://doi.org/10.1016/j.bar.2014.06.001

Faccio, M., Marchica, M. T., \& Mura, R. (2016). CEO gender, corporate risk-taking, and the efficiency of capital allocation. Journal of Corporate Finance, 39, 193-209. http://dx.doi.org/10.1016/j.jcorpfin.2016.02.008

Fama, E. F., \& Jensen, M. C. (1983). Agency problems and residual claims. The journal of law and Economics, 26(2), 327-349.

Feldman, R., Govindaraj, S., Livnat, J., \& Segal, B. (2010). Management's tone change, post earnings announcement drift and accruals. Review of Accounting Studies, 15(4), 915-953. https://doi.org/10.1007/s11142-009-9111-x

FRC. (2011) Guidance On Board Effectiveness. London, March.

FRC. (2016). The UK corporate governance code. London, September.

García-Sánchez, I. M., Suárez-Fernández, O., \& Martínez-Ferrero, J. (2019). Female directors and impression management in sustainability reporting. International Business Review, 28(2), 359-374. https://doi.org/10.1016/j.ibusrev.2018.10.007 
Gounopoulos, D., \& Pham, H. (2018). Financial Expert CEOs and Earnings Management Around Initial Public Offerings. The International Journal of Accounting, 53(2), 102-117. https://doi.org/10.1016/j.intacc.2018.04.002

Gray, R., Kouhy, R., \& Lavers, S. (1995). Corporate social and environmental reporting: a review of the literature and a longitudinal study of UK disclosure. Accounting, Auditing \& Accountability Journal, 8(2), 47-77. https://doi.org/10.1108/09513579510146996

Gul, F. A., Srinidhi, B., \& Ng, A. C. (2011). Does board gender diversity improve the informativenes s of stock prices?. Journal of Accounting and Economics, 51(3), 314-338. https:// doi:10.1016/j.jacceco.2011.01.005

Habib, A., \& Hossain, M. (2013). CEO/CFO characteristics and financial reporting quality: A review. Research in Accounting Regulation, 25(1), 88-100. http://dx.doi.org/10.1016/j.racreg.2012.11.002

Ham, C., Seybert, N., \& Wang, S. (2018). Narcissism is a bad sign: CEO signature size, investment, and performance. Review of Accounting Studies, 23(1), 234-264. https://DOI 10.1007/s11142-0179427-x

Hambrick, D. C., \& Mason, P. A. (1984). Upper echelons: The organization as a reflection of its top managers. Academy of management review, 9(2), 193-206. https://doi.org/10.5465/amr.1984.4277628

Henry, E. (2008). Are investors influenced by how earnings press releases are written?. The Journal of Business Communication, 45(4), 363-407. https://doi. org/10.1177/0021943608319388

Henry, E., \& Leone, A. J. (2016). Measuring qualitative information in capital markets research: Comparison of alternative methodologies to measure disclosure tone. The Accounting Review, 91(1), 153-178. https://doi. org/10.2308/accr-51161

Ho, S. S., Li, A. Y., Tam, K., \& Zhang, F. (2015). CEO gender, ethical leadership, and accounting conservatism. Journal of Business Ethics, 127(2), 351-370. https:// DOI 10.1007/s 10551-013-20440

Huang, H. W., Rose-Green, E., \& Lee, C. C. (2012). CEO age and financial reporting quality. Accounting Horizons, 26(4), 725-740. http:// DOI: 10.2308/acch-50268

Huang, X., Teoh, S. H., \& Zhang, Y.(2014). Tone management. The Accounting Review, 89(3), 1083 1113. https://doi.org/10.2308/accr-50684 
Hussainey, K., Schleicher, T., \& Walker, M. (2003). Undertaking large-scale disclosure studies when AIMR-FAF ratings are not available: the case of prices leading earnings. Accounting and business research,33(4), 275-294. https://doi. org/10.1080/00014788.2003.9729654

Iatridis, G. E. (2016). Financial reporting language in financial statements: Does pessimism restrict the potential for managerial opportunism?. International Review of Financial Analysis, 45, 1-17. https://doi.org/10.1016/j.irfa.2016.02.004

Ibrahim, A. E. A., \& Hussainey, K. (2019). Developing the narrative risk disclosure measurement. International Review of Financial Analysis, 64, 126-144. https://doi.org/10.1016/j.irfa.2019.05.006

Jiang, F., Zhu, B., \& Huang, J. (2013). CEO's financial experience and earnings management. Journal of Multinational Financial Management, 23(3), 134-145. http://dx.doi.org/10.1016/j.mulfin.2013.03.005

Kothari, S. P., Li, X., \& Short, J. E. (2009). The effect of disclosures by management, analysts, and business press on cost of capital, return volatility, and analyst forecasts: A study using content analysis. The Accounting Review, 84(5), 1639-1670. https://doi. org/10.2308/accr.2009.84.5.1639

Lee, J., \& Park, J. (2019). The Impact of Audit Committee Financial Expertise on Management Discussion and Analysis (MD\&A) Tone. European Accounting Review, 28(1), 129-150. https://doi.org/10.1080/09638180.2018.1447387

Li, F. (2010). The information content of forward-looking statements in corporate filings - A naïve Bayesian machine learning approach. Journal of Accounting Research, 48(5), 1049-1102. https://doi.org/10.1111/j.1475-679X.2010.00382.x

Li, F. (2011). Managers' self-serving attribution bias and corporate financial policies. Available at SSRN 1639005.

Liao, L., Luo, L., \& Tang, Q. (2015). Gender diversity, board independence, environmental committee and greenhouse gas disclosure. The British Accounting Review, 47(4), 409-424. http://dx.doi.org/10.1016/j.bar.2014.01.002

Libby, R., \& Rennekamp, K. (2012). Self-serving attribution bias, overconfidence, and the issuance of management forecasts. Journal of Accounting Research, 50(1), 197-231. https:// DOI: 10.1111/j.1475-679X.2011.00430.X 
Lin, C., Lin, P., Song, F. M., \& Li, C. (2011). Managerial incentives, CEO characteristics and corporate innovation in China's private sector. Journal of Comparative Economics, 39(2), 176-190. https:// doi:10.1016/j.jce.2009.12.001

Linsley, P. M., \& Shrives, P. J. (2006). Risk reporting: A study of risk disclosures in the annual reports of UK companies. The British Accounting Review, 38(4), 387-404. https://doi.org/10.1016/j.bar.2006.05.002

Loughran, T., \& McDonald, B. (2011). When is a liability not a liability? Textual analysis, dictionaries, and 10-Ks. The Journal of Finance, 66(1), 35-65. https://doi.org/10.1111/j.15406261.2010.01625.x

Loughran, T., \& McDonald, B. (2016). Textual analysis in accounting and finance: A survey. Journal of Accounting Research, 54(4), 1187-1230. https://doi.org/10.1111/1475-679X.12123

Mangena, M., \& Pike, R. (2005). The effect of audit committee shareholding, financial expertise and size on interim financial disclosures. Accounting and Business Research, 35(4), 327-349.

Marquez-Illescas, G., Zebedee, A. A., \& Zhou, L. (2019). Hear Me Write: Does CEO Narcissism Affect Disclosure?. Journal of Business Ethics, 1-17. https://doi. org/10.1007/s10551-01 8-3796-3

Mason, E. S., \& Mudrack, P. E. (1996). Gender and ethical orientation: A test of gender and occupational socialization theories. Journal of Business Ethics, 15(6), 599-604.

McClelland, P. L., Barker III, V. L., \& Oh, W. Y. (2012). CEO career horizon and tenure: Future performance implications under different contingencies. Journal of Business Research,65(9), 13871393. http:// doi:10.1016/j.jbusres.2011.09.003

Melloni, G., Stacchezzini, R., \& Lai, A. (2016). The tone of business model disclosure: an impression management analysis of the integrated reports. Journal of Management \& Governance, 20(2), 295320. https:// DOI 10.1007/s10997-015-9319-z

Merkley, K. J. (2014). Narrative disclosure and earnings performance: Evidence from R\&D disclosures. The Accounting Review, 89(2), 725-757. https://doi.org/10.2308/accr-50649

Olsen, K. J., Dworkis, K. K., \& Young, S. M. (2014). CEO narcissism and accounting: A picture of profits. Journal of Management Accounting Research, 26(2), 243-267. https:// DOI: 10.2308/jmar50638

Osma, B. G., \& Guillamón-Sa orín, E. (2011). Corporate governance and impression management in annual results press releases. Accounting, Organizations and Society, 36(4-5), 187-208. https:// doi:10.1016/j.aos.2011.03.005 
Palvia, A., Vähämaa, E., \& Vähämaa, S. (2015). Are female CEOs and chairwomen more conservative and risk averse? Evidence from the banking industry during the financial crisis. Journal of Business Ethics, 131(3), 577-594. https:// DOI 10.1007/s10551-014-2288-3

Peni, E. (2014). CEO and Chairperson Characteristics and firm performance. Journal of Management \& Governance, 18(1), 185-205. https:// DOI 10.1007/s10997-012-9224-7

Pennebaker, J. W., Mehl, M. R., \& Niederhoffer, K. G. (2003). Psychological aspects of natural language use: Our words, our selves. Annual review of psychology, 54(1), 547-577. https://doi.org/10.1146/annurev.ps ych.54.101601.145041

Plöckinger, M., Aschauer, E., Hiebl, M. R., \& Rohatschek, R. (2016). The influence of individual executives on corporate financial reporting: A review and outlook from the perspective of upper echelons theory. Journal of Accounting Literature, 37, 55-75. https://doi.org/10.1016/j.acclit.2016.09.002

Poletti-Hughes, J., \& Briano-Turrent, G. C. (2019). Gender diversity on the board of directors and corporate risk: A behavioural agency theory perspective. International Review of Financial Analysis, 62, 80-90. https://doi.org/10.1016/j. irfa.2019.02.004

Price, S. M., Doran, J. S., Peterson, D. R., \& Bliss, B. A. (2012). Earnings conference calls and stock returns: The incremental informativeness of textual tone. Journal of Banking \& Finance, 36(4), 9921011. https://doi.org/10.1016/j.jbankfin.2011.10.013

Rahman, S. (2019). Discretionary tone, annual earnings and market returns: Evidence from UK Interim Management Statements. International Review of Financial Analysis, 101384. https://doi.org/10.1016/j.irfa.2019.101384

Raskin, R., \& Terry, H. (1988). A principal-components analysis of the Narcissistic Personality Inventory and further evidence of its construct validity. Journal of personality and socialpsychology, 54(5), 890.

Schleicher, T. (2012). When is good news really good news?. Accounting and Business Research, 42(5), 547-573. https://doi. org/10.1080/00014788.2012.685275

Schleicher, T., \& Walker, M. (2010). Bias in the tone of forward-looking narratives. Accounting and business research, 40(4), 371-390. https://doi.org/10.1080/00014788.2010.9995318

Serfling, M. A. (2014). CEO age and the riskiness of corporate policies. Journal of Corporate Finance, 25, 251-273. http://dx.doi. org/10.1016/j.jcorpf in.2013.12.01 
Smith, M., \& Taffler, R. J. (2000). The chairman's statement-a content analysis of discretionary narrative disclosures. Accounting, Auditing \& Accountability Journal, 13(5), 624-647. https://doi.org/10.1108/09513570010353738

Sprenger, T. O., Sandner, P. G., Tumasjan, A., \& Welpe, I. M. (2014). News or noise? Using Twitter to identify and understand company-specific news flow. Journal of Business Finance \& Accounting, 41(7-8), 791-830. https://doi. org/10.1111/jbfa.12086

Tan, H. T., Ying Wang, E., \& Zhou, B. O. (2014). When the use of positive language backfires: The joint effect of tone, readability, and investor sophistication on earnings judgments. Journal of Accounting Research, 52(1), 273-302. https://doi.org/10.1111/1475-679X.12039

Tetlock, P. C. (2007). Giving content to investor sentiment: The role of media in the stock market. The Journal of finance, 62(3), 1139-1168. https://doi.org/10.1111/j.1540-6261.2007.01232.x

Wales, W. J., Patel, P. C., \& Lumpkin, G. T. (2013). In pursuit of greatness: CEO narcissism, entrepreneurial orientation, and firm performance variance. Journal of Management Studies, 50(6), 1041-1069. https://doi: 10.1111/joms.12034

Wang, M., \& Kelan, E. (2013). The gender quota and female leadership: Effects of the Norwegian gender quota on board chairs and CEOs. Journal of business ethics, 117(3), 449-466. https:// DOI $10.1007 / \mathrm{s} 10551-012-1546-5$

Wisniewski, T. P., \& Yekini, L. S. (2015). Stock market returns and the content of annual report narratives. Accounting Forum, 39(4), 281-294. https://doi.org/10.1016/j.accfor.2015.09.001

Yekini, L. S., Wisniewski, T. P., \& Millo, Y. (2016). Market reaction to the positiveness of annual report narratives. The British Accounting Review, 48(4), 415-430. https://doi.org/10.1016/j.bar.2015.12.001

Zalata, A. M., Ntim, C., Aboud, A., \& Gyapong, E. (2018). Female CEOs and core earnings quality: new evidence on the ethics versus risk-aversion puzzle. Journal of Business Ethics, 1-20. https://doi.org/10.1007/s10551-018-3918-y

Zalata, A. M., Tauringana, V., \& Tingbani, I. (2018). Audit committee financial expertise, gender, and earnings management: Does gender of the financial expert matter?. International Review of Financial Analysis, 55, 170-183. https://doi.org/10.1016/j.irfa.2017.11.002

Zhang, H., Ou, A. Y., Tsui, A. S., \& Wang, H. (2017). CEO humility, narcissism and firm innovation: A paradox perspective on CEO traits. The Leadership Quarterly, 28(5), 585-604. https://doi.org/10.1016/j. leaqua.2017.01.003 
Zhou, Y., Kara, A., \& Molyneux, P. (2019). Chair-CEO generation gap and bank risk-taking. The British Accounting Review, 51(4), 352-372. https://doi.org/10.1016/j.bar.2019.03.005 
Table (1): Variables definition

\begin{tabular}{|c|c|}
\hline Variable & Definition \\
\hline Positive_Tone & $\begin{array}{l}\text { Number of positive words divided by the total number of words in } \\
\text { annual report (to control for the length) }\end{array}$ \\
\hline Net_Tone & $\begin{array}{l}\text { Number of (positive words-negative words) divided by the total } \\
\text { number of words in annual report. }\end{array}$ \\
\hline CEO Narciss ism & $\begin{array}{l}\text {-Percentage of first-person pronounces in CEO letter to shareholders. } \\
\text {-Score from } 1 \text { to } 5 \text { as follow: } \\
\text { 1: No photo of CEO } \\
\text { 2: CEO photo with other executives } \\
\text { 3: CEO photo alone and occupied less than half the page } \\
\text { 4: CEO photo alone and occupied more than half the page } \\
\text { 5: CEO photo occupied the whole page }\end{array}$ \\
\hline CEO Age & The age of CEO at the end of fiscal year. \\
\hline CEO Gender & Dummy variable $=1$ if the CEO is female and $=0$ if the CEO is male. \\
\hline CEO Financial expertise & $\begin{array}{l}\text { Dummy variable }=1 \text { if the CEO has previous financial experience in } \\
\text { either a banking or investment company, in a large auditing firm } \\
\text { or in a finance-related role (e.g., financial advisor, VP of finance, } \\
\text { CFO); zero otherwise. }\end{array}$ \\
\hline CEO Tenure & Number of years serving as CEO in the company \\
\hline CEO Duality & $\begin{array}{l}\text { Dummy variable }=1 \text { if the CEO is also the Chairman of the board, } \\
\text { and }=0 \text { otherwise. }\end{array}$ \\
\hline CEO Founder & $\begin{array}{l}\text { Dummy variable }=1 \text { if the CEO is the founder of the company, and } \\
=0 \text { otherwise }\end{array}$ \\
\hline CEO Compensation & $\begin{array}{l}\text { Natural log for total salaries and bonuses that the CEO gets from the } \\
\text { company. }\end{array}$ \\
\hline Board Size & Total number of members in the board. \\
\hline Board Independence & Percentage of independent directors in the board. \\
\hline Board Diversity & Percentage of females on board of directors per year. \\
\hline AC Independence & Percentage of independent members in the audit committee. \\
\hline
\end{tabular}




\begin{tabular}{|c|l|}
\hline FRC & $\begin{array}{l}\text { Dummy variable }=1 \text { for the years after the Financial Reporting } \\
\text { Council narrative reporting guidance (2015-2018) }\end{array}$ \\
\hline FOG Index & $\begin{array}{l}\text { As a measurement of readability }=0.4 \text { [(words/sentences) }+100 \\
\text { (complex words/words)]. }\end{array}$ \\
\hline Firm Size & Natural logarithm of total assets at the end of fiscal year. \\
\hline Firm Value & $\begin{array}{l}\text { Measured by BTM: Ratio of book value to share price at the end of } \\
\text { fiscal year. }\end{array}$ \\
\hline Sales growth & Change in sales relative to the previous fiscal year. \\
\hline Leverage & Total liabilities over total assets. \\
\hline Profitability & Return in Equity (ROE) measured as net income before dividends by \\
& the year-end common equity. \\
\hline Dividend & Measured as dividend per share. \\
\hline
\end{tabular}


Table (2): Descriptive statistics

\begin{tabular}{lrrrrr}
\hline Variable & Obs & Mean & Std.Dev. & Min & Max \\
\hline Pos Tone & 2437 & 0.018 & 0.004 & 0.002 & 0.059 \\
Net Tone & 2437 & 0.002 & 0.005 & -0.098 & 0.055 \\
CEO_Age & 2437 & 53.1 & 6.58 & 32 & 79 \\
CEO_Gender & 2437 & .046 & .209 & 0 & 1 \\
CEO Finexp & 2437 & 0.205 & 0.404 & 0 & 1 \\
CEO NAR & 2437 & 0.027 & 0.08 & 0 & 0.074 \\
CEO Photo & 2437 & 2.869 & 0.694 & 1 & 5 \\
CEO Duality & 2437 & 0.03 & 0.169 & 0 & 1 \\
CEO Tenure & 2437 & 6.14 & 5.72 & 0.083 & 41.5 \\
CEO Comp & 2437 & 14.196 & 0.841 & 9.876 & 18.069 \\
CEO_Fonder & 2437 & 0.073 & 0.26 & 0 & 1 \\
AC IND & 2437 & 97.983 & 8.674 & 0 & 100 \\
B_Diversity & 2437 & 15.583 & 11.032 & 0 & 57.143 \\
B_Size & 2437 & 8.467 & 2.085 & 3 & 19 \\
B_IND & 2437 & 60.884 & 12.984 & 0 & 92.857 \\
FRC & 2437 & 0.437 & 0.496 & 0 & 1 \\
FOG & 2437 & 21.671 & 2.98 & 14.122 & 83.406 \\
Size & 2437 & 7.209 & 1.70 & 2.323 & 12.927 \\
Lev & 2437 & 21.78 & 18.3 & 0 & 165.5 \\
DPS & 2437 & 0.22 & 0.34 & 0 & 3.07 \\
BTM & 2437 & 0.49 & 0.57 & -5.45 & 12.08 \\
Profit & 2437 & 24.9 & 92.9 & -345.6 & 240.9 \\
Sales growth & 2437 & 8.246 & 22.416 & -93.0 & 383.89 \\
& & & & & \\
\hline
\end{tabular}


Table (3): Correlation Matrix

\begin{tabular}{|c|c|c|c|c|c|c|c|c|c|c|}
\hline VAR & Pos & Age & gender & Fin Exp & NAR & DUL & Tenure & COMP & Found & AC_IND \\
\hline pos & 1 & & & & & & & & & \\
\hline Age & $-0.031^{*}$ & 1 & & & & & & & & \\
\hline Gender & $-0.037^{*}$ & $-0.065 * *$ & 1 & & & & & & & \\
\hline FinExp & -0.016 & $-0.078 * * *$ & $-0.034^{*}$ & 1 & & & & & & \\
\hline NAR & $0.042 * *$ & $0.051^{* *}$ & $0.050 * *$ & -0.004 & 1 & & & & & \\
\hline DUL & $-0.038^{*}$ & $0.201 * * *$ & $-0.38 *$ & -0.023 & -0.016 & 1 & & & & \\
\hline tenure & $-0.037^{*}$ & $0.253 * * *$ & $-0.058 * * *$ & $-0.066 * *$ & -0.016 & $0.082 * * *$ & 1 & & & \\
\hline Found & $-0.092 * * *$ & $0.142 * * *$ & $-0.062 * * *$ & -0.017 & $-0.069 * * *$ & $0.081 * * *$ & $0.379 * * *$ & $0.044^{* *}$ & 1 & \\
\hline AC_IND & $-0.071 * * *$ & $0.056 * *$ & 0.028 & $0.041 * *$ & $0.061 * * *$ & $-0.080 * * *$ & 0.010 & $0.073 * * *$ & -0.020 & 1 \\
\hline B_Size & $0.039 *$ & $0.049 * *$ & $0.043 * *$ & $0.051 * *$ & $0.321 * * *$ & $-0.047 * *$ & -0.029 & $0.366 * * *$ & -0.018 & $0.053 * * *$ \\
\hline B_IND & $0.057 * * *$ & $0.056 * * *$ & $0.046 * *$ & 0.023 & $0.197 * * *$ & $-0.081 * * *$ & $-0.087 * * *$ & $0.236 * * *$ & $-0.106 * * *$ & $0.425 * * *$ \\
\hline B_div & $0.156 * * *$ & $0.096 * * *$ & $0.205^{* * *}$ & -0.023 & $0.228 * * *$ & $-0.041 * *$ & -0.013 & $0.198 * * *$ & $-0.038 *$ & $0.144 * * *$ \\
\hline FOG & $-0.274 * * *$ & 0.002 & $-0.036^{*}$ & 0.008 & $0.046 * *$ & -0.023 & -0.031 & -0.024 & -0.026 & 0.017 \\
\hline Size & $-0.151 * * *$ & $0.078 * * *$ & 0.028 & -0.025 & $0.380 * * *$ & $-0.037^{*}$ & $-0.034^{*}$ & $0.287^{* * *}$ & -0.051 & $0.050 * *$ \\
\hline BTM & $-0.139 * * *$ & $0.065 * * *$ & 0.029 & -0.006 & $-0.089 * * *$ & $-0.047 * *$ & $-0.040 * *$ & $-0.072 * * *$ & -0.018 & 0.008 \\
\hline Profit & 0.023 & $0.099 * * *$ & -0.012 & 0.039* & $0.028^{*}$ & -0.006 & 0.001 & 0.016 & $0.109 * * *$ & 0.007 \\
\hline S_grwth & 0.030 & -0.024 & -0.005 & 0.010 & $0.013^{*}$ & -0.002 & -0.017 & -0.011 & -0.004 & 0.003 \\
\hline
\end{tabular}




\begin{tabular}{|c|c|c|c|c|c|c|c|c|c|}
\hline VAR & B_Size & B_IND & B_DIV & FOG & Size & Lev & BTM & Profit & S_grwth \\
\hline B_Size & 1 & & & & & & & & \\
\hline B_IND & $0.133^{* * *}$ & 1 & & & & & & & \\
\hline B_div & $0.249 * * *$ & $0.305^{* * *}$ & 1 & & & & & & \\
\hline FOG & 0.026 & -0.019 & -0.010 & 1 & & & & & \\
\hline Size & $0.340 * * *$ & $0.242 * * *$ & $0.094 * * *$ & $0.043^{* *}$ & 1 & & & & \\
\hline Lev & $0.116 * * *$ & $0.058 * * *$ & $0.103 * * *$ & 0.039* & $0.049 * *$ & 1 & & & \\
\hline BTM & -0.005 & -0.017 & $-0.055^{* * *}$ & -0.009 & $0.073 * * *$ & $-0.116 * * *$ & 1 & & \\
\hline Profit & 0.022 & 0.003 & $0.092 * * *$ & 0.026 & -0.029 & 0.011 & $-0.178 * * *$ & 1 & \\
\hline S_grwth & -0.024 & -0.019 & -0.001 & -0.008 & -0.005 & -0.015 & $-0.045^{* *}$ & -0.008 & 1 \\
\hline
\end{tabular}

*Significance at the $10 \%$ level; **significance at the $5 \%$ level; *** significance at the $1 \%$ level 
Table (4): De te rminants of NDT

\begin{tabular}{|c|c|c|}
\hline \multirow{2}{*}{$\begin{array}{l}\text { Pos_Tone } \\
\text { CEO_NAR }\end{array}$} & $(1)$ & $(2)$ \\
\hline & & $\begin{array}{l}0.0041 * * * \\
(4.23)\end{array}$ \\
\hline CEO_age & $\begin{array}{l}-0.0032^{* *} \\
(-1.91)\end{array}$ & $\begin{array}{l}-0.0023^{* *} \\
(-2.04)\end{array}$ \\
\hline CEO_gender & $\begin{array}{l}-0.0081^{* *} \\
(-1.97)\end{array}$ & $\begin{array}{l}-0.0041 \\
(-1.29)\end{array}$ \\
\hline CEO_FinExp & $\begin{array}{l}-0.0025^{* *} \\
(-1.39)\end{array}$ & $\begin{array}{l}-0.0041^{* *} \\
(-2.51)\end{array}$ \\
\hline AC_IND & $\begin{array}{l}-0.0028^{* * *} \\
(-3.15)\end{array}$ & $\begin{array}{l}-0.0019 * * \\
(-2.47)\end{array}$ \\
\hline B_IND & $\begin{array}{l}-9.3206^{*} \\
(-1.48)\end{array}$ & $\begin{array}{l}-0.0012^{*} \\
(-1.87)\end{array}$ \\
\hline B_diversity & $\begin{array}{l}0.0025^{* * *} \\
(3.31)\end{array}$ & $\begin{array}{l}0.0021 * * * \\
(2.76)\end{array}$ \\
\hline CEO_duality & $\begin{array}{l}-0.0059^{*} \\
(-1.49)\end{array}$ & $\begin{array}{l}-0.0079 * * \\
(-1.99)\end{array}$ \\
\hline CEO_Tenure & $\begin{array}{l}-0.0017 \\
(-1.33)\end{array}$ & $\begin{array}{l}-7.7706 \\
(-0.65)\end{array}$ \\
\hline CEO_Compensation & $\begin{array}{l}9.8811^{* * *} \\
(4.10)\end{array}$ & $\begin{array}{l}8.3911 * * * \\
(3.67)\end{array}$ \\
\hline CEO_founder & $\begin{array}{l}-0.0098^{* * *} \\
(-3.51)\end{array}$ & $\begin{array}{l}-0.0081^{* * *} \\
(-2.92)\end{array}$ \\
\hline B_Size & $\begin{array}{l}0.0057 \\
(1.41)\end{array}$ & $\begin{array}{l}0.0017 \\
(0.44)\end{array}$ \\
\hline FRC & $\begin{array}{l}0.0013^{* * *} \\
(3.39)\end{array}$ & $\begin{array}{l}0.0013^{* * *} \\
(3.37)\end{array}$ \\
\hline FOG & $\begin{array}{l}-0.0031^{* * *} \\
(-14.27)\end{array}$ & $\begin{array}{l}-0.0031 * * * \\
(-14.22)\end{array}$ \\
\hline Size & $\begin{array}{l}-2.0318^{* * *} \\
(-8.05)\end{array}$ & $\begin{array}{l}-1.8308^{* * *} \\
(-7.67)\end{array}$ \\
\hline Leverage & $\begin{array}{l}-4.4406^{*} \\
(-1.17)\end{array}$ & $\begin{array}{l}-3.6906 \\
(1.00)\end{array}$ \\
\hline DIV & $\begin{array}{l}0.0075^{* * *} \\
(3.27)\end{array}$ & $\begin{array}{l}0.0074^{* * *} \\
(3.24)\end{array}$ \\
\hline BTM & $\begin{array}{l}-0.0045^{* * *} \\
(-3.93)\end{array}$ & $\begin{array}{l}-0.0054^{* * *} \\
(-4.48)\end{array}$ \\
\hline Sales growth & $\begin{array}{l}9.7408^{*} \\
(1.81)\end{array}$ & $\begin{array}{l}8.9080^{*} \\
(1.66)\end{array}$ \\
\hline Profitability & $\begin{array}{l}3.5807^{*} \\
(0.42)\end{array}$ & $\begin{array}{l}2.4607 \\
(0.35)\end{array}$ \\
\hline Constant & $\begin{array}{l}0.0205^{* * *} \\
(1.83)\end{array}$ & $\begin{array}{l}0.0201 * * * \\
(1.82)\end{array}$ \\
\hline Year FE & YES & YES \\
\hline Firm FE & YES & YES \\
\hline Observations & 2,437 & 2,437 \\
\hline VIF & 1.64 & 1.61 \\
\hline $\mathrm{R} 2$ & $19.32 \%$ & $20.45 \%$ \\
\hline
\end{tabular}

*Significance at the $10 \%$ level; **significance at the $5 \%$ level; *** significance at the $1 \%$ level. Coefficient for each variable is reported, and t test values appear in brackets. 
Table (5): CG moderation effects:

\begin{tabular}{|c|c|c|}
\hline Pos_Tone & 1 & 2 \\
\hline \multirow[t]{2}{*}{ CEO_NAR } & $0.013 * *$ & \\
\hline & $(2.33)$ & \\
\hline \multirow[t]{2}{*}{ B_IND } & -2.7616 & -0.001 \\
\hline & $(-0.36)$ & $(-1.64)$ \\
\hline \multirow[t]{2}{*}{ CEO_NAR*B_IND } & $-0.0015^{* *}$ & \\
\hline & $(-1.87)$ & \\
\hline \multirow[t]{2}{*}{ CEO_gender } & -0.0015 & $-0.0018 * *$ \\
\hline & $(-0.47)$ & $(-2.20)$ \\
\hline \multirow[t]{2}{*}{ B_diversity } & $0.0027^{* * *}$ & $0.0025 * * *$ \\
\hline & (3.49) & (3.17) \\
\hline \multirow[t]{2}{*}{ CEO_gender*B_diversity } & & $0.0065 * *$ \\
\hline & & $(2.24)$ \\
\hline \multirow[t]{2}{*}{ CEO_age } & $-0.0015^{*}$ & $-0.0015^{*}$ \\
\hline & $(-1.33)$ & $(-1.35)$ \\
\hline \multirow[t]{2}{*}{ CEO_FinExp } & $-0.0032 * *$ & $-0.0032 * *$ \\
\hline & $(-1.93)$ & $(-1.91)$ \\
\hline \multirow[t]{2}{*}{ CEO_DUL } & $-0.0069 *$ & -0.0063 \\
\hline & $(-1.72)$ & $(-1.57)$ \\
\hline \multirow[t]{2}{*}{ CEO_Tenure } & -0.0001 & -0.0014 \\
\hline & $(-1.19)$ & $(-1.08)$ \\
\hline \multirow[t]{2}{*}{ CEO_Compensation } & $9.4411 * * *$ & $1.2610 * * *$ \\
\hline & (3.96) & $(4.51)$ \\
\hline \multirow[t]{2}{*}{ CEO_Founder } & $-0.0091 * * *$ & $-0.0010 * * *$ \\
\hline & $(-3.32)$ & $(-3.62)$ \\
\hline \multirow[t]{2}{*}{ AC_IND } & $-0.0026 * * *$ & $-0.0027 * * *$ \\
\hline & $(-3.07)$ & $(-3.19)$ \\
\hline \multirow[t]{2}{*}{ B_Size } & 0.0034 & 0.0051 \\
\hline & $(0.89)$ & $(1.29)$ \\
\hline \multirow[t]{2}{*}{ FRC } & $0.0012 * * *$ & $0.0013^{* * *}$ \\
\hline & (3.25) & $(3.40)$ \\
\hline \multirow[t]{2}{*}{ FOG } & $-0.0032 * * *$ & $-0.0031 * * *$ \\
\hline & $(-14.41)$ & $(-14.13)$ \\
\hline \multirow[t]{2}{*}{ Size } & $-1.8819 * * *$ & $-1.8508 * * *$ \\
\hline & $(-7.32)$ & $(-7.78)$ \\
\hline \multirow[t]{2}{*}{ Leverage } & -2.7506 & -2.5206 \\
\hline & $(-0.74)$ & $(-0.67)$ \\
\hline \multirow[t]{2}{*}{ BTM } & $-0.0049 * * *$ & $-0.0056 * * *$ \\
\hline & $(-4.12)$ & $(-4.68)$ \\
\hline \multirow[t]{2}{*}{ Profitability } & 1.6108 & 1.6107 \\
\hline & $(0.02)$ & $(0.22)$ \\
\hline \multirow[t]{2}{*}{ Sales_growth } & $1.0107^{*}$ & $1.0107^{*}$ \\
\hline & $(1.87)$ & $(1.87)$ \\
\hline \multirow[t]{2}{*}{ Constant } & $0.0198 * * *$ & $0.0201 * * *$ \\
\hline & $(1.78)$ & $(1.83)$ \\
\hline YearFE & YES & YES \\
\hline Firm FE & YES & YES \\
\hline Observations & 2,437 & 2,437 \\
\hline VIF & 2.46 & 1.96 \\
\hline R2 & $19.34 \%$ & $19.62 \%$ \\
\hline
\end{tabular}

*Significance at the $10 \%$ level; **significance at the $5 \%$ level; *** significance at the $1 \%$ level.

Coefficient for each variable is reported, and t test values appear in brackets. 
Table (6): alte rnative measure of CEO narcissism:

\begin{tabular}{|c|c|c|}
\hline Pos_Tone & (1) & $(2)$ \\
\hline CEO_NAR & $0.0071^{* * *}$ & $0.0074 * * *$ \\
\hline (Photo) & (7.18) & $(7.44)$ \\
\hline \multirow[t]{2}{*}{ B_IND } & $-0.0011^{*}$ & $-0.0014 * *$ \\
\hline & $(-1.78)$ & $(-2.20)$ \\
\hline \multirow[t]{2}{*}{ NAR*B_IND } & & $-0.0042 * *$ \\
\hline & & $(-3.10)$ \\
\hline \multirow[t]{2}{*}{ CEO_age } & $-0.0018^{* *}$ & $-0.0018^{* *}$ \\
\hline & $(-1.68)$ & $(-1.66)$ \\
\hline \multirow[t]{2}{*}{ CEO_gender } & $-0.0037^{*}$ & -0.0039 \\
\hline & $(-1.11)$ & $(-1.22)$ \\
\hline \multirow[t]{2}{*}{ CEO_FinExp } & $-0.0042^{* *}$ & $-0.0042 * *$ \\
\hline & $(-2.54)$ & $(-2.52)$ \\
\hline \multirow[t]{2}{*}{$A C \_I N D$} & $-0.0028 * * *$ & $-0.0027 * *$ \\
\hline & $(-3.17)$ & $(-3.23)$ \\
\hline \multirow[t]{2}{*}{ B_diversity } & $0.0025^{* * *}$ & $0.0022^{* * *}$ \\
\hline & $(3.32)$ & $(2.94)$ \\
\hline \multirow[t]{2}{*}{ CEO_duality } & $-0.0077^{*}$ & $-0.0081 * *$ \\
\hline & $(-1.94)$ & $(-2.06)$ \\
\hline \multirow[t]{2}{*}{ CEO_Tenure } & -2.5106 & -1.6706 \\
\hline & $(-0.20)$ & $(-0.13)$ \\
\hline \multirow[t]{2}{*}{ CEO_Compensation } & $9.8911 * * *$ & $8.6711 * * *$ \\
\hline & $(4.21)$ & $(3.67)$ \\
\hline \multirow[t]{2}{*}{ CEO_founder } & $-0.0086 * * *$ & $-0.0082 * * *$ \\
\hline & $(-3.14)$ & $(-2.98)$ \\
\hline \multirow[t]{2}{*}{ B_Size } & 0.0004 & 0.0029 \\
\hline & $(1.05)$ & $(0.74)$ \\
\hline \multirow[t]{2}{*}{ FRC } & $0.0013^{* * *}$ & $0.0012^{* * *}$ \\
\hline & $(3.36)$ & $(3.26)$ \\
\hline \multirow[t]{2}{*}{ FOG } & $-0.0032 * * *$ & $-0.0031 * * *$ \\
\hline & $(-14.42)$ & $(-14.52)$ \\
\hline \multirow[t]{2}{*}{ Size } & $-1.5408 * * *$ & $-1.7508^{* * *}$ \\
\hline & $(-6.39)$ & $(-7.01)$ \\
\hline \multirow[t]{2}{*}{ Leverage } & $-2.2606^{*}$ & -2.3706 \\
\hline & $(-0.60)$ & $(0.63)$ \\
\hline \multirow[t]{2}{*}{ DIV } & $0.0075^{* * *}$ & $0.0074 * * *$ \\
\hline & $(3.27)$ & (3.24) \\
\hline \multirow[t]{2}{*}{ BTM } & $-0.0056 * * *$ & $-0.0054 * * *$ \\
\hline & $(-4.19)$ & $(-4.54)$ \\
\hline \multirow[t]{2}{*}{ Sales growth } & $9.7208 *$ & $9.0218^{*}$ \\
\hline & $(1.81)$ & $(1.80)$ \\
\hline \multirow[t]{2}{*}{ profitability } & $1.2018^{*}$ & 6.2018 \\
\hline & $(0.02)$ & $(0.09)$ \\
\hline \multirow[t]{2}{*}{ Constant } & $0.0168^{* *}$ & $0.0189 * * *$ \\
\hline & (0.64) & $(1.66)$ \\
\hline Year FE & YES & YES \\
\hline Firm FE & YES & YES \\
\hline Observations & 2,437 & 2,437 \\
\hline VIF & 1.64 & 1.61 \\
\hline R2 & $21.14 \%$ & $21.42 \%$ \\
\hline
\end{tabular}

*Significance at the $10 \%$ level; **significance at the $5 \%$ level; *** significance at the $1 \%$ level.

Coefficient for each variable is reported, and t test values appear in brackets. 
Table (7): Robustness test for NDT determinants

\begin{tabular}{|c|c|c|}
\hline \multirow{2}{*}{$\begin{array}{l}\text { Net_Tone } \\
\text { CEO_NAR }\end{array}$} & (1) & (2) \\
\hline & & $\begin{array}{l}0.0019 \\
(1.27)\end{array}$ \\
\hline CEO_age & $\begin{array}{l}-0.0023^{*} \\
(-1.38)\end{array}$ & $\begin{array}{l}-0.0023 * \\
(-1.37)\end{array}$ \\
\hline CEO_gender & $\begin{array}{l}-0.0029^{*} \\
(-0.60)\end{array}$ & $\begin{array}{l}-0.0029 * \\
(-0.60)\end{array}$ \\
\hline CEO_FinExp & $\begin{array}{l}-0.0073^{* *} \\
(-0.29)\end{array}$ & $\begin{array}{l}-0.0068^{* *} \\
(-0.27)\end{array}$ \\
\hline AC_IND & $\begin{array}{l}-0.0035^{* * *} \\
(-2.71)\end{array}$ & $\begin{array}{l}-0.0036^{* * *} \\
(-2.77)\end{array}$ \\
\hline B_IND & $\begin{array}{l}-0.0025^{* * *} \\
(-2.62)\end{array}$ & $\begin{array}{l}-0.0025^{* * *} \\
(-2.62)\end{array}$ \\
\hline B_diversity & $\begin{array}{l}0.0019 \\
(1.60)\end{array}$ & $\begin{array}{l}0.0021^{*} \\
(1.84)\end{array}$ \\
\hline CEO_duality & $\begin{array}{l}-0.0034^{*} \\
(-0.56)\end{array}$ & $\begin{array}{l}-0.0032^{*} \\
(-0.52)\end{array}$ \\
\hline CEO_Tenure & $\begin{array}{l}-0.0015 \\
(-0.75)\end{array}$ & $\begin{array}{l}-0.0016 \\
(-0.82)\end{array}$ \\
\hline CEO_Compensation & $\begin{array}{l}1.2910^{* * *} \\
(3.56)\end{array}$ & $\begin{array}{l}1.3910^{* * *} \\
(3.82)\end{array}$ \\
\hline CEO_founder & $\begin{array}{l}-0.0049 * \\
(-1.15)\end{array}$ & $\begin{array}{l}-0.0056^{*} \\
(-1.32)\end{array}$ \\
\hline B_Size & $\begin{array}{l}0.0016 \\
(0.26)\end{array}$ & $\begin{array}{l}0.0024 \\
(0.40)\end{array}$ \\
\hline FRC & $\begin{array}{l}0.0005 * \\
(0.84)\end{array}$ & $\begin{array}{l}0.0004^{*} \\
(0.74)\end{array}$ \\
\hline FOG & $\begin{array}{l}-0.0051^{*} \\
(-1.53)\end{array}$ & $\begin{array}{l}-0.0045^{*} \\
(-1.46)\end{array}$ \\
\hline Size & $\begin{array}{l}-2.6508^{* * *} \\
(-7.03)\end{array}$ & $\begin{array}{l}-2.4608^{* * *} \\
(-6.56)\end{array}$ \\
\hline Leverage & $\begin{array}{l}-0.0002^{* * *} \\
(-3.59)\end{array}$ & $\begin{array}{l}-0.0002^{* * *} \\
(-3.70)\end{array}$ \\
\hline DIV & $\begin{array}{l}0.0012^{* * *} \\
(2.98)\end{array}$ & $\begin{array}{l}0.0012^{* * *} \\
(2.98)\end{array}$ \\
\hline BTM & $\begin{array}{l}-0.0099 * * * \\
(-5.39)\end{array}$ & $\begin{array}{l}-0.0094^{* * *} \\
(-5.71)\end{array}$ \\
\hline Sales growth & $\begin{array}{l}1.2707^{*} \\
(1.55)\end{array}$ & $\begin{array}{l}1.2907^{*} \\
(1.56)\end{array}$ \\
\hline profitability & $\begin{array}{l}6.4017 \\
(0.58)\end{array}$ & $\begin{array}{l}7.5907 \\
(0.69)\end{array}$ \\
\hline Constant & $\begin{array}{l}0.0009 \\
(0.52)\end{array}$ & $\begin{array}{l}0.0011 \\
(0.60)\end{array}$ \\
\hline Year FE & YES & YES \\
\hline Firm FE & YES & YES \\
\hline Observations & 2,437 & 2,437 \\
\hline VIF & 1.63 & 1.63 \\
\hline R2 & $12.36 \%$ & $12.74 \%$ \\
\hline
\end{tabular}

*Significance at the $10 \%$ level; $* *$ significance at the $5 \%$ level; $* * *$ significance at the $1 \%$ level. Coefficient for each variable is reported, and t test values appear in brackets. 
Table (8): Robus tness test for CG moderation effects

\begin{tabular}{|c|c|c|}
\hline Net_Tone & 1 & 2 \\
\hline \multirow[t]{2}{*}{ CEO_NAR } & 0.0069 & \\
\hline & $(0.083)$ & \\
\hline \multirow[t]{2}{*}{ B_IND } & $-0.0021 * *$ & $-0.0025 * * *$ \\
\hline & $(-1.82)$ & $(-2.60)$ \\
\hline \multirow[t]{2}{*}{ CEO_NAR*B_IND } & $-0.0076 *$ & \\
\hline & $(-0.62)$ & \\
\hline \multirow[t]{2}{*}{ CEO_gender } & $-0.0029 *$ & $-0.0032 * *$ \\
\hline & $(-0.61)$ & $(-2.56)$ \\
\hline \multirow[t]{2}{*}{ B_diversity } & $0.0022^{*}$ & $0.0016^{*}$ \\
\hline & $(1.86)$ & $(1.40)$ \\
\hline CEO_gender*B_diversity & & $\begin{array}{l}0.0011^{* *} \\
(2.55)\end{array}$ \\
\hline \multirow[t]{2}{*}{ CEO_age } & $-0.0023 *$ & $-0.0023^{*}$ \\
\hline & $(-1.36)$ & $(-1.32)$ \\
\hline \multirow[t]{2}{*}{ CEO_FinExp } & $-0.0065^{*}$ & $-0.0045^{*}$ \\
\hline & $(-0.26)$ & $(-0.17)$ \\
\hline \multirow[t]{2}{*}{ CEO_DUL } & $-0.0034 *$ & $-0.0032 *$ \\
\hline & $(-0.55)$ & $(-0.53)$ \\
\hline \multirow[t]{2}{*}{ CEO_Tenure } & 0.0015 & 0.0017 \\
\hline & $(0.80)$ & $(0.88)$ \\
\hline \multirow[t]{2}{*}{ CEO_Compensation } & $1.3910 * * *$ & $1.4910 * * *$ \\
\hline & $(3.84)$ & $(4.16)$ \\
\hline \multirow[t]{2}{*}{ CEO_Founder } & $-0.0054^{*}$ & $-0.0061^{*}$ \\
\hline & $(-1.28)$ & $(-1.44)$ \\
\hline AC_IND & $\begin{array}{l}-0.0035^{* * *} \\
(-2.72)\end{array}$ & $\begin{array}{l}-0.0036 * * * \\
(-2.77)\end{array}$ \\
\hline \multirow[t]{2}{*}{ B_Size } & 0.0023 & 0.0036 \\
\hline & $(0.38)$ & $(0.59)$ \\
\hline \multirow[t]{2}{*}{ FRC } & $0.0004^{*}$ & 0.0005 \\
\hline & $(0.73)$ & $(0.75)$ \\
\hline \multirow[t]{2}{*}{ FOG } & $-0.0051^{*}$ & $-0.0045^{*}$ \\
\hline & $(-1.51)$ & $(-1.34)$ \\
\hline \multirow[t]{2}{*}{ Size } & $-2.3108 * * *$ & $-2.3408 * * *$ \\
\hline & $(-6.08)$ & $(-6.45)$ \\
\hline \multirow[t]{2}{*}{ Leverage } & $-0.0002 * * *$ & $-0.0002 * * *$ \\
\hline & $(-3.68)$ & $(-3.68)$ \\
\hline \multirow[t]{2}{*}{ BTM } & $-0.0010 * * *$ & $-0.0011 * * *$ \\
\hline & $(-5.69)$ & $(-6.09)$ \\
\hline \multirow[t]{2}{*}{ Profitability } & 7.4017 & 8.9017 \\
\hline & $(0.67)$ & $(0.81)$ \\
\hline \multirow[t]{2}{*}{ Sales_growth } & $1.2907^{*}$ & $1.3107^{*}$ \\
\hline & $(1.57)$ & (1.59) \\
\hline \multirow[t]{2}{*}{ Constant } & 0.0012 & 0.0011 \\
\hline & $(0.69)$ & $(0.63)$ \\
\hline YearFE & YES & YES \\
\hline Firm FE & YES & YES \\
\hline Observations & 2,437 & 2,437 \\
\hline VIF & 3.29 & 1.94 \\
\hline R2 & $12.14 \%$ & $12.30 \%$ \\
\hline
\end{tabular}

*Significance at the $10 \%$ level; **significance at the 5\% level; *** significance at the $1 \%$ level.

Coefficient for each variable is reported, and t test values appear in brackets. 